
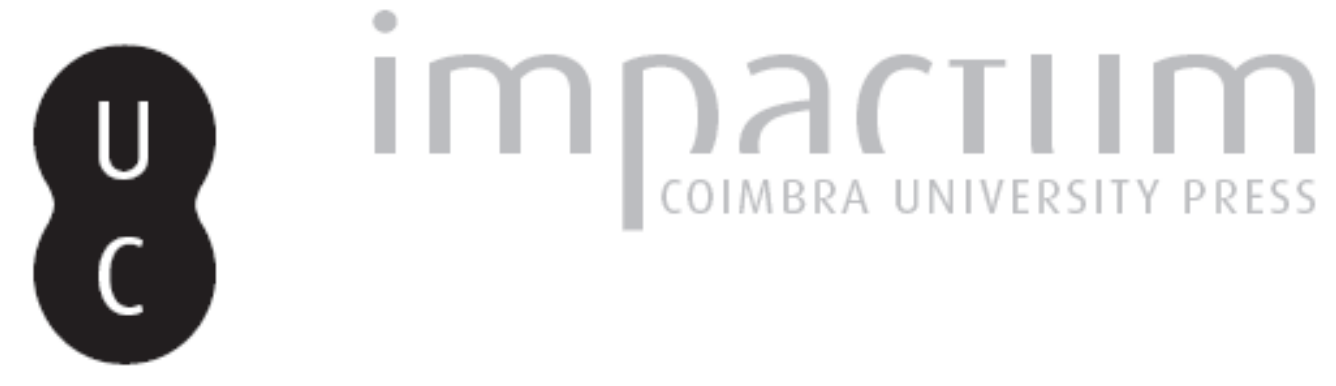

\title{
Legislação urbanística e produção de riscos: o caso do PEU das vargens (Rio de Janeiro, Brasil)
}

Autor(es): $\quad$ Name, Leo; Montezuma, Rita de Cássia Martins; Gomes, Elisa Sesana

Publicado por: Associação Portuguesa de Riscos, Prevenção e Segurança

URL persistente:

URI:http://hdl.handle.net/10316.2/36074

DOI:

DOI:http://dx.doi.org/10.14195/1647-7723_18_18

Accessed : $\quad$ 26-Apr-2023 12:54:04

A navegação consulta e descarregamento dos títulos inseridos nas Bibliotecas Digitais UC Digitalis, UC Pombalina e UC Impactum, pressupõem a aceitação plena e sem reservas dos Termos e Condições de Uso destas Bibliotecas Digitais, disponíveis em https://digitalis.uc.pt/pt-pt/termos.

Conforme exposto nos referidos Termos e Condições de Uso, o descarregamento de títulos de acesso restrito requer uma licença válida de autorização devendo o utilizador aceder ao(s) documento(s) a partir de um endereço de IP da instituição detentora da supramencionada licença.

Ao utilizador é apenas permitido o descarregamento para uso pessoal, pelo que o emprego do(s) título(s) descarregado(s) para outro fim, designadamente comercial, carece de autorização do respetivo autor ou editor da obra.

Na medida em que todas as obras da UC Digitalis se encontram protegidas pelo Código do Direito de Autor e Direitos Conexos e demais legislação aplicável, toda a cópia, parcial ou total, deste documento, nos casos em que é legalmente admitida, deverá conter ou fazer-se acompanhar por este aviso.

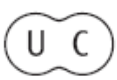




\section{territorium}

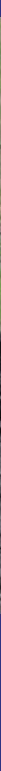

\section{Afirmar as Ciências Cindínicas}

Revista da Associação Portuguesa de Riscos, Prevenção e Segurança 
territorium 18, 2011, 201-218

journal homepage: http:// www.nicif.pt/ riscos/ Territorium/ numeros_publicados

LEGISLAÇÃO URBANÍSTICA E PRODUÇÃO DE RISCOS: O CASO DO PEU DAS VARGENS (RIO DE J ANEIRO, BRASIL)*

Leo Name

Departamento de Geografia, Pontifícia Universidade Católica do Rio de J aneiro (PUC-Rio)

leoname@puc-rio.br

Rita de Cássia Martins Montezuma

Departamento de Geografia, Pontifícia Universidade Católica do Rio de J aneiro (PUC-Rio) montezum@puc-rio.br

Elisa Sesana Gomes

Departamento de Geografia, Pontifícia Universidade Católica do Rio de J aneiro (PUC-Rio) elisa.sesana@gmail.com

\section{RESUMO}

A partir de uma visão multidisciplinar (geografia, ecologia, direito urbano, arquitetura e urbanismo) este artigo pretende abordar os potenciais riscos relacionados ao recém-aprovado Plano Estruturação Urbana das Vargens (Rio de J aneiro, Brasil). Esta avaliação será realizada observando-se os riscos potenciais em três dimensões: a jurídico-política, a urbano-arquitetônica e a geobiofísica.

Palavras-chaves: riscos, paisagem, PEU das Vargens, Rio de J aneiro.

\section{RESUMEN}

Legislación urbanística y producción de riesgos: el caso de PEU das Vargens (Rio de Janeiro, Brasil) - Desde una perspectiva de varias disciplinas (geografía, ecología, derecho urbano, arquitectura y urbanismo) este artículo tiene como objetivo abordar los posibles riesgos relacionados con el recientemente aprobado Plan de Estructuración Urbana de las Vargens - PEU das Vargens (Río de J aneiro, Brasil). Esta evaluación se realizará teniendo en cuenta los riesgos potenciales en tres dimensiones: jurídico-política-, urbano-arquitectónica e a geobiofísica.

Palabras-claves: riesgos, paisaje, planificación urbana, PEU das Vargens, Rio de J aneiro.

\section{RESUMÉ}

La législation urbaine et la production de risques: le cas de PEU das Vargens (Rio de J aneiro, Brésil) - En utilisant une approche pluridisciplinaire (de la géographie, de la écologie, de le droit urbain, de l' architecture et de l'urbanisme), cet article tente de répondre aux risques potentiels liés au Plan de Structuration Urbaine des Vargens - PEU das Vargens (Rio de J aneiro, Brésil). Cette évaluation sera effectuée en tenant compte des risques potentiels dans les trois dimensions suivantes: juridique-politique, urbaine-architecturale et geobiophysique.

Mots-clés: risques, paysage, PEU das Vargens, Rio de J aneiro.

\section{ABSTRACT}

Urban law and production of risks: the case of PEU das Vargens (Rio de J aneiro, Brazil) - Using a multidisciplinary approach (geography, ecology, urban law, architecture and urbanism) this paper aims to clarify the potential risks related to the recently approved Urban Plan of Vargens - PEU das Vargens (Rio de J aneiro, Brazil). This evaluation will focus on the potential risks in three dimensions: juridical and political, urban and architectural and, finally, geobiophisical.

Key words: risk, landscape, PEU das Vargens, Rio de J aneiro.

\footnotetext{
* O texto deste artigo corresponde à comunicação apresentada ao II Congresso Internacional de Riscos e VI Encontro Nacional, tendo sido submetido para revisão em 27-05-2010, tendo sido aceite para publicação em 05-07-2010.

Este artigo é parte integrante da Revista Territorium, n. 0 18, 2011, RISCOS, ISBN: 0872- 8941.
} 


\section{Introdução}

Em 27 de outubro de 2009 foi promulgada pela Câmara Municipal do Rio de J aneiro a Lei Complementar 104/ 09, que vem a ser o Projeto de Estruturação Urbana dos bairros de Vargem Grande, Vargem Pequena, Camorim e parte dos bairros do Recreio dos Bandeirantes, Barra da Tijuca e J acarepaguá, mais conhecido como PEU das Vargens. Os referidos bairros encontram-se na Baixada de J acarepaguá, com cerca de 160 km², localizada na região litorânea oeste da cidade do Rio de J aneiro e situada em uma extensa planície sedimentar de depósitos recentes do período quaternário, formando um imenso triângulo circundado nas laterais por dois maciços (Tijuca e Pedra Branca) e apresentando expressivo complexo lagunar (Fig. 1). Na sua base localiza-se, ainda, uma faixa de praia do litoral atlântico. Em conjunto, ali se têm áreas úmidas, mangues, faixas de restinga e florestas (Fig. 2).

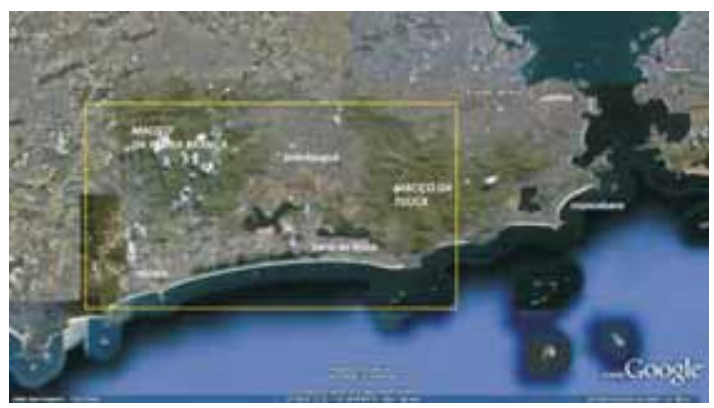

Fig. 1 - Localização aproximada da Baixada de Jacarepaguá (Fonte: Google Earth, 2010, adaptado)

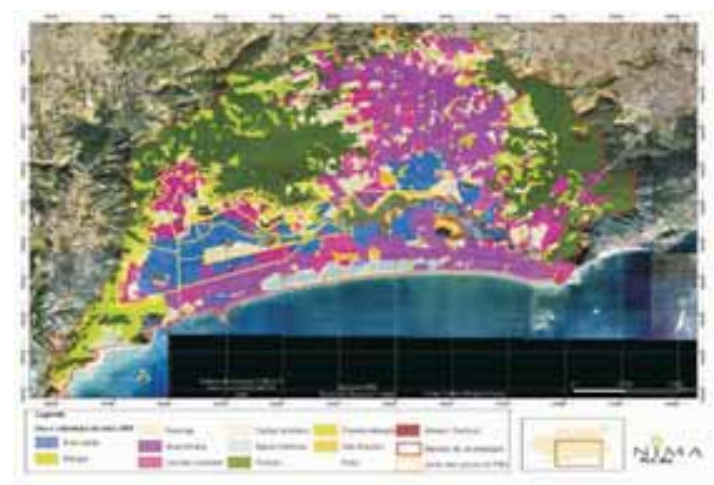

Fig. 2 - Uso do Solo e Cobertura Vegetal da Baixada de J acarepaguá, com marcação de limites e setores do PEU das Vargens (Fonte: NIMA/ PUC-Rıo, 2009, adaptado)

Bem distante da área central e da prestigiosa zona sul carioca, a área foi alvo, em 1969, do Plano Piloto para a Urbanização da Baixada Compreendida entre a Barra da Tijuca, o Pontal de Sernambetiba e Jacarepaguá. Mais conhecido como Plano Piloto da Barra da Tijuca e Jacarepaguá, é de autoria do arquiteto e urbanista Lúcio Costa e seguiu os mesmos princípios modernistas do planejamento e desenho urbanos em "tabula rasa" que ele também utilizara no Plano Piloto de Brasília, de 1957: anterior à Declaração da Conferência das Nações Unidas sobre o Meio Ambiente Humano (Declaração de Estocolmo) que em 1972 reconheceria a necessidade de preservação do meio ambiente natural e cultural, o texto de Plano Piloto refere-se à grande biodiversidade da Baixada de Jacarepaguá e as suas características físico-ambientais (como alta variação pluviométrica, extensas áreas úmidas, dentre outros fatores bióticos e físicos relevantes) a partir de vagas noções sobre "pecularidades paisagísticas que importam preservar", nas palavras de seu próprio autor (Costa, 1969, p. 8), traçando vias e definindo parâmetros de uso e ocupação do solo sem grandes preocupações com o ambiente físico e a paisagem natural, embora seja importante deixar claro que a área mais a oeste, justamente onde se tem hoje o PEU da Vargens, tenha comparativamente recebido muito menor intervenção (ver Fig. 3).

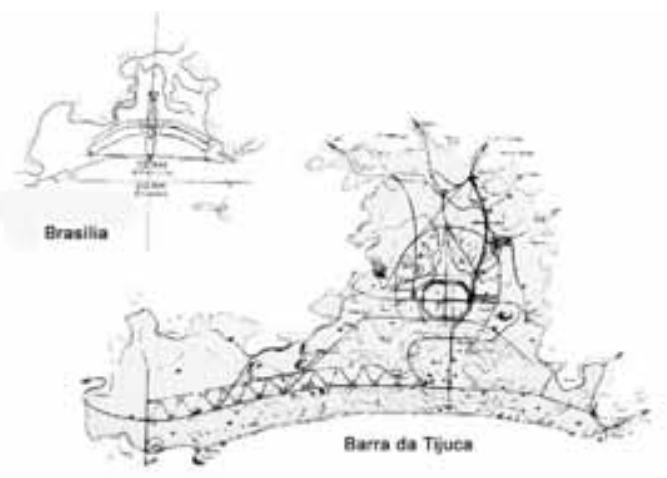

Fig. 3 - Comparação entre o Plano Piloto de Brasília (1957) e o Plano Piloto da Barra da Tijuca e J acarepaguá (Fonte: Resente \& LEITÃo, 2003)

Passados mais de quarenta anos da proposta de Lucio Costa, Jacarepaguá é hoje bairro de urbanização consolidade e densidade elevada, ao passo que no processo histórico de ocupação da Barra da Tijuca e do Recreio dos Bandeirantes conjugaram-se em um modelo de urbanização dispersa grandes condomínios fechados, shopping centers, baixa provisão de infraestruturas e bolsões de pobreza, que em conjunto causaram forte degradação da área e exercem até hoje enorme pressão ambiental sobre os outros três bairros, ainda pouco ocupados. Este crescimento da urbanização vem ocasionando, sobre este área de cotas extremamente baixas, progressiva e expressiva diminuição da cobertura vegetal, conforme dados da própria prefeitura da cidade (Fig. 4, 5 e 6). Bairros como Vargem Grande, Vargem Pequena e Camorim, por sua vez, ainda que estejam suj eitos a toda a sorte de ocupações irregulares (inclusive com a ação de milicianos), são valorizados por certas camadas sociais por hoje manterem uma paisagem que, por conta de tipologias de chácaras com lotes maiores e baixas taxas de ocupação, emana, ainda que de forma um tanto insipiente, certa "ruralidade". 


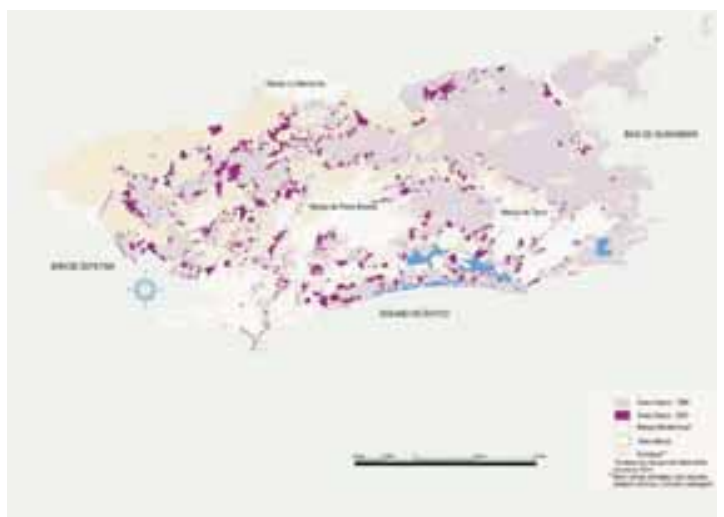

Fig. 4 - Crescimento da Urbanização - Município do Rio J aneiro, 1984/ 2001. Fonte: Instituto Pereira Passos (2005)

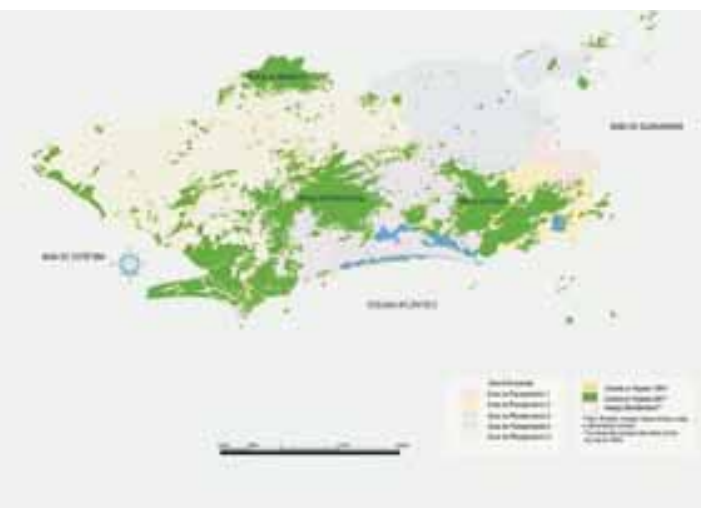

Fig. 5 - Variação da Cobertura Vegetal Nativa - Município do Rio J aneiro, 1984/ 2001. Fonte: Instituto Pereira Passos (2005)

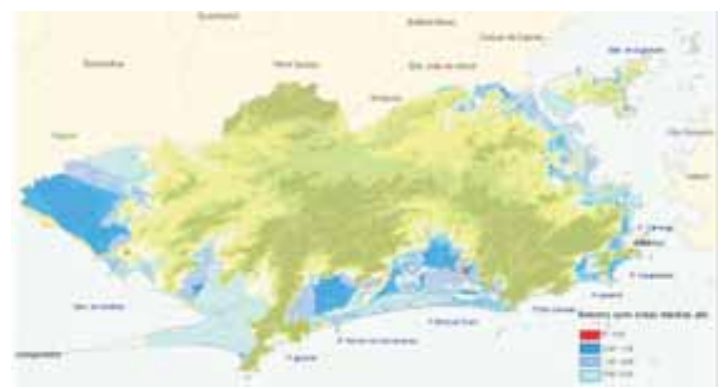

Fig. 6 - Cotas médias até 0,80 - 1,50 - 3,00 - 5,00 metros, por setor censitário. Fonte: Instituto Pereira Passos (2005)

Nesse sentido, a aprovação de um proj eto de estruturação urbana em local tão singular seria oportunidade para se produzir um marco legal que, através da consideração de intrínsecos fatores físicos-ambientais, moldasse um ou mais modelos de ocupação que gerassem o mínino de impacto ao ambiente. Ao invés disso, além de o texto ter sido aprovado em prazo exíguo (apenas doz dias), sem participação da sociedade, ignorando vários aspectos legais e sob a questionável justificativa de se conseguir recursos financeiros para a realização dos J ogos Olímpicos de 2016 na cidade, o PEU das Vargens especifica elevadíssimos parâmetros urbanísticos que, se concretizados, aumentarão enormemente a ocupação e a densidade urbanas. Produz-se, com a referida lei, um modelo de ocupação para esta área ambientalmente complexa e, hoje, já bastante carente de infraestrutura básica, que além de induzir intensas mais-valiasfundiárias para o incremento do mercado imobiliário, potencializa vários riscos socioambientais, aos quais pretendemos aqui discutir a partir de uma visão multidisciplinar.

A noção de "risco", ainda que venha sendo cada vez mais incorporada ao vocabulário de inúmeras proposições acadêmicas, já é bastante controversa no próprio corpo teórico da geografia: por um lado, por existirem sérios problemas de tradução de palavras do inglês para as línguas latinas; por outro lado, devido a termos ligados à geografia e a outras ciências ambientais relacionados a esta problemática muitas vezes serem inadvertidamente tratados como sinônimos. Fora da geografia, recentes concepções da sociologia complexificaram ainda mais a discussão, alçando o risco à explicação totalizante da sociedade contemporânea - uma "sociedade de risco", afinal. Por fim, a discussão de riscos necessariamente faz conjugar dados objetivos e subjetivos, estratégias de ação enérgica do Estado na esfera do planejamento territorial e valores morais e éticos que constroem as próprias definição e percepção de risco e condicionam as ações de controle e precaução.

Por essas razões, na primeira seção deste trabalho realizaremos breve discussão sobre este lodoso terreno epistemológico, visando a esclarecer tais ambiguidades. Após tal discussão e mediante o fato de o objeto deste artigo ser uma lei, apontaremos, por um lado, que a definição, o planejamento e a prevenção de riscos, assim como a legislação, inclusive a urbanística, dialogam com o espaço a partir de pré-concepções e idealizações do futuro, sejam negativas ou positivas; por outro lado, que a concretização do que é previsto em quaisquer leis ou a efetivação de riscos anteriormente percebidos, mapeados ou categorizados são de fato sempre incertas, desafiam técnicos e relativizam o saber perito e, assim, podem por isso estimular abusos de autoridade antes, durante ou após a percepção do risco ou a produção da norma legal - mas, mesmo assim, nem riscos nem normas podem ser completamente ignorados. Por fim, apontaremos sobre a possibilidade de uma norma urbanística, quando restrita a determinado tipo ou concepção de ordenamento territorial, ignorar outros fatores (como por exemplo os geobiofísicos) e se configurar, ela mesma, como uma indutora de riscos (tais quais os ambientais - no sentido pleno da relação entre sociedade e natureza), o que é particularmente perverso no processo de urbanização das cidades brasileiras.

$\mathrm{Na}$ segunda seção do trabalho, então, inseriremos - PEU das Vargens aprovado nesta discussão sobre legislação, cidades e produção de riscos, apresentando em três dimensões os potenciais riscos que seu inerente modelo de ocupação urbana pode acarretar: a dimensão jurídico-política, em que se percebe que um longo processo de democratização, participação popular 
e construção de diretrizes e instrumentos legais do planejamento urbano é ignorado pelo PEU das Vargens e, por isso, potencialmente deslegitimado; a dimensão urbano-arquitetônica, complementar à primeira, em que se apresentará o modelo de ocupação intrínseco à lei, cuja densidade populacional prevista é enorme, em contraposição à exígua provisão infraestrutural, o que compromete a qualidade ambiental, é dispendiosa por exigir investimentos públicos e/ ou privados para sua realização, altera a paisagem e potencializa processos de gentrificação que tornam ainda mais vulneráveis as populações de baixa renda que há muito ocupam a área; e, por fim, a dimensão dos processos geobiofísicos em que a possibilidade de danos sobre os ecossistemas configura os riscos de perda da biodiversidade, ressaltando que ambos podem resultar tanto na perda na escala local, quanto nas escalas regional ou global. Ressalta-se que as três dimensões estão interligadas, à medida que a legislação induz uma ocupação que, se concretizada, é necessariamente onerosa aos cofres públicos e/ ou ao mercado e que potencializa os riscos relacionados às funções ecossistêmicas. Tal situação, por sua vez, sobrecarrega novamente as dimensões política e econômica a partir da necessidade de políticas públicas e mais investimentos na mitigação do desequilíbrio causado pelas substituições das funções que gratuitamente os sistemas geobiofísicos fornecem.

\section{0 risco, a cidade e a lei}

A noção de risco ambiental foi pela primeira vez abordada por Talbot PAGE (1978). Ele assim nomeou o que percebeu como novo tipo de problema ambiental que diferiria em natureza dos problemas, então mais perceptíveis, da poluição e do esgotamento de recursos. Este problema rapidamente vinha aumentando de importância e poderia, segundo ele, tornar-se o tipo dominante a ser vencido por técnicos e pesquisadores. Desde então, a discussão sobre riscos ambientais só vêm crescendo, sendo o termo foco de gama ampla de investigadores das ciências naturais e sociais, além de profissionais da administração pública e do planejamento e ordenamento físico-territoriais.

PAGE já percebia, entretanto, que a problemática do risco se relaciona de forma direta à incerteza e ao desconhecimento das verdadeiras dimensões do problema ambiental, sejam eles direcionados aos seus efeitos futuros ou às decisões do presente para se sanar ou evitar o risco: a bem da verdade, o melhor dos peritos jamais tem como assegurar que o que se está observando como em risco tornar-se-á fato, isto é, quando ocorrerá o possível dano e se o mesmo ocorrerá; e, quanto mais se sabe sobre determinado tipo de risco, mais chances há para se descobrir outros possíveis riscos num mesmo lugar ou situação (ANEAS DE CASTRo, 2000; BECK, 1998;
Egler, 1996; November, 1994 e 2006). A noção de risco e a atuação sobre o mesmo trazem contraditoriamente, pois, indefinição conceitual (a respeito da natureza, processos e consequências de risco) e imprecisão (a respeito das formas de intervenção sobre os mesmos), fatores que se sempre foram categoricamente rejeitados pela ciência moderna, tornam-se cada vez mais indissociáveis de seu modus operandi contemporâneo (SANTOS, 2003).

Ao mesmo tempo polissêmica e imprecisa, pragmática e ativa, além de absolutamente indissociável dos conceitos de "ambiente" e "meio geográfico", tão caros à geografia, o risco se desdobra em epistemologias, reflexões e questionamentos sobre a modernidade e suas formas espaciais, ao passo que mais e mais estudos são realizados visando simples e objetivamente à minimização dos riscos oriundos de eventos tão díspares como furacões, avalanches, terremotos e tormentas, deslizamentos e inundações, vazamentos químicos e radiações nucleares, sobretudo quando ocorridos nas cidades. Mas compreender todas as nuanças dos vários tipos de risco (que podem ser risco natural, risco tecnológico, risco social etc.), apontam, dentre outros, Egler (op. cit.) e CASTRo et. al. (2005), implica avaliações que determinam e estão determinadas por diversas escalas, com diferentes escopos temporais e definindo múltiplos e complexos níveis de gestão (do local ao global). Além disso, explicam Marandola JR. \& Hogan (2004), "risco" se confunde ou ao menos se relaciona com termos como "ameaça", "perigo", "suscetibilidade", "vulnerabilidade", "desastre" e "catástrofe", dentre outros termos, além de ter seu entendimento condicionado à acepção de hazard, palavra inglesa que não encontra tradução direta para o português, francês ou espanhol, o que demanda bastante atenção: apesar de não ser possível transpor para o português toda a complexidade que a noção de hazard carrega, normalmente a palavra é traduzida para "perigo" ou "ameaça".

Iniciados em fins da década de 1920 nos Estados Unidos a partir de motivação tecnocrática, na alçada da provisão infraestrutural (sobretudo objetivando a contenção de inundações) e da melhor relação custo-benefício (Aneas de Castro, op. cit; Marandola J R. \& Hogan, op. cit; WHITE, 1975), os estudos sobre hazards gradativamente receberam aportes teórico-metodológicos da geologia, climatologia e, sobretudo, geografia, que os ampliaram para uma visão integrada de sociedade e natureza, sendo sua compreensão do processo de ocupação humana dos espaços a estrutura dos mecanismos de intervenção e gestão do território. Assim, os eventos que passam a ser considerados como hazards não são tão somente naturais: ocorrem na interface entre sociedade e natureza e, desse modo, também não se relacionam necessariamente a uma força natural que é externa e extrema e que, por isso, potencialmente tenha capacidade de trazer enorme dano às ocupações humanas. As modernas 
cidades, metrópoles e megalópoles, com usos do solo inadequados, técnicas ineficientes, tecnologias predatórias e com suas estratificação, marginalização, segregação e exclusão espaciais podem ser consideradas, elas mesmas, potentes hazards urbanos (J ONES, 1993). O mundo urbano é dotado de contínuos processos de (des)agregação, (re)construção e (auto)destruição que geram, além de danos, muito medo, e, por isso mesmo, permanentemente sobrepõe os componentes físicos a significantes e significados sociais que, segundo November (1994), jamais podem ser vistos isoladamente.

A discussão sobre riscos vêm também ganhando certo corpus sociológico que Ihe tem dotado de conteúdo explicativo geohistórico e totalizante, sendo Ulrich BECK (1998) o principal nome a afirmar que a modernidade capitalista, por si mesma, produz uma sociedade de riscos. Pois no âmago da modernidade está a concepção de futuro baseada na idéia de progresso, por sua vez apoiada em formas de pensamento técnico-científico ou leigo que concebem a natureza como algo externo ao humano, por isso passível de constante apropriação e depredação. A modernidade também historicamente aliou a transformação da matéria em energia à economia de bens de consumo, gerando enorme quantidade de resíduos; induziu a adoção e universalização de tecnologias ambientalmente dispendiosas e predatórias; gerou exploração e dependência econômicas entre povos e grupos sociais; condicionou formações socioeconômicas baseadas na marginalização, estratificação e segregação. Nesse sentido, podemos a partir deste autor interpretar o processo de urbanização como apenas um dos hazards da arriscada modernidade, isto é, a espacialização de muitos dos processos perversos a ela associados.

\section{Mas como se diferenciar hazards de riscos?}

Em sua revisão sobre tais noções, David J ones (op. cit.) afirma que os riscos são o produto mais complexo dos hazards. O risco é uma situação que interliga no futuro determinados objetos a certos eventos e que traz incerteza, medo e insegurança. Estar em risco é, enfim, estar suscetível à ocorrência de um hazard. Dito de outros modos: a implicação adicional do risco é o hazard realmente se concretizar, isto é, existirem características que montem certa suscetibilidade a determinado perigo ou ameaça; o hazard é o fenômeno potencial, cujo perigo ou ameaça eminente dá vulnerabilidade ao espaço (que pode ter em si mesmo certas características que aumentem esta vulnerabilidade), ao passo que o risco é a probabilidade do hazard ocorrer e o dano é a sua efetivação; quando o dano ocorre de forma vultosa, com pouca ou nenhuma possibilidade de se conter, retardar ou diminuir seus efeitos negativos e normalmente prolongados, tem-se o desastre ou catástrofe (ANEAS DE Castro, op. cit; SMith, 1992).
Mas a urbanização moderna, com todos os seus intrínsecos problemas, apesar de em muito ser espontânea ou descontrolada (sobretudo nos países periféricos, como o Brasil), é, ao mesmo tempo, submetida a normas legais. Por sua vez, a legislação urbanística que condiciona a regulação do solo é, ao menos em tese, um instrumento que tem como intencionalidade coibir muitos dos problemas relacionados às aglomerações urbanas, que vão da concentração de terras nas mãos de poucos e privilegiados proprietários à ocupação de áreas de risco, da provisão de equipamentos à delimitação de áreas de proteção, dentre outras inúmeras situações. Determinase por este tipo de norma jurídica que a sociedade construa coletivamente seu locus, um espaço a qual se direciona certa priorização de usos e formas de ocupação para que seja mais adequado e tenha mais qualidade e funcionalidade. Mas este espaço não é o espaço real: é um espaço do devir, é um espaço normativo. Trata-se de uma abstração que, ainda que tenha enorme influência sobre as ações sociais e políticas do "mundo real", só existe dentro de uma norma ou, melhor ainda, na resultante de diversas normas (muitas vezes contraditórias entre si).

Isto nos obriga a refletir sobre as normas e sua relação com o espaço urbano. As normas, afinal, são formas de discurso que, não estando restritas ao campo jurídico e apresentando-se em muitos contextos ou situações, necessariamente são referência, jamais realidade empírica. Segundo Nino (1998), as normas podem ser: simples regras determinativas, que apenas regulam certa atividade (como as regras de jogos); diretivas ou técnicas, que indicam meios para se alcançar determinado fim, mas sem se dirigir à vontade do destinatário (como um manual de instruções, por exemplo); e as prescrições que emanam da vontade do emissor da norma, a que se chama de "autoridade normativa", sendo destinadas a um agente, chamado "sujeito normativo". Para fazer o sujeito conhecer de que sua vontade seja conduzida de determinada forma, a autoridade promulga a norma e, se quiser, dá a esta vontade certa efetividade, incluindo-se sanção ou ameaça de castigo. As normas jurídicas seriam, portanto, prescrições, normalmente com várias sanções, sendo a autoridade jurídica o Estado que "ordena algo, prescreve, quer que algo deva acontecer. 0 dever-ser - a norma - é o sentido de um querer, de um ato de vontade, [... e é o sentido de um ato dirigido à conduta de outrem, de um ato cujo sentido é que um outro (ou outros) deve (ou devem) conduzir-se de determinado modo" (KeLSEN, 1986). O suj eito normativo a ser conduzido é a sociedade e, no caso das normas urbanísticas, também seu espaço.

Como apontado por SовотA (1996), o texto legal é uma técnica concreta usada por determinada pessoa, grupo social ou sociedade em situação específica, que é sistema aberto constituído por várias influências sociais, econômicas e culturais. Para a autora, toda lei guarda em si certa vontade de antever o futuro, querendo 
prever cada conflito individual e assim organizar a vida humana em comum. Existe a crença que o processo de formulação e decisão jurídicas consiste em encontrar e aplicar as normas instrumentais, entendidas como capazes de definir e dirigir a esfera do "dever ser" tão exata e logicamente quanto um dia se supôs que as leis da física clássica dirigiriam a natureza. Mas as leis, além de não terem garantia de obediência, são sempre dúbias, seja por conta de uma gama imprevisível de interesses pessoais ou de grupo que influencia seu processo de formulação, seja por conta da variabilidade de (im)possibilidades de sua aplicação. Mais ainda, na sua comparação com outras normas (inclusive as morais) que se sobrepõem à realidade, têm-se diversas formas de interpretação para uma mesma lei. Para a autora, por fim, o discurso legal torna possível criar a ilusão de certeza em uma esfera que é da total incerteza.

Nesse sentido, as normas urbanísticas, então, são parte da produção do espaço, no sentido lefebvriano do termo (LefeBVRe, 1981), pois se por um lado são meros esquemas de interpretação ou formas de representação que fornecem inteligibilidades possíveis a se direcionar a determinados espaços, por outro lado organizam a apreensão do real (CHARTIER, 1990; FouCAult, 2002). Além disso, através das classificações, divisões e delimitações das leis os espaços são concebidos, percebidos, construídos e vividos. Em outras palavras, as normas urbanísticas se aproximam da discussão sobre riscos por criarem um espaço normativo que não é a realidade e designar à sociedade os parâmetros para sua realização como tal num futuro incerto. Também nelas estão as sanções àqueles que se desviarem deste projeto de um espaço futuro. Os parâmetros e sanções tornam este espaço próprio do dever-ser jurídico porque quer ser pela norma realidade mais ainda não o é - e relacionam-se basicamente ao onde, ao como e ao quanto da ocupação do solo urbano e da construção sobre o solo urbano. Mas como aponta Gonçalves (2006), a lei necessariamente diminui a complexidade do real e, portanto, a norma urbanística alija o espaço urbano de sua complexidade própria.

Diante de toda a discussão apresentada, pode-se perceber uma relação direta entre incerteza, normas urbanísticas, e potencialização de riscos. Minimamente, na execução de normas urbanísticas já editadas, há sempre incertezas sobre o espaço normativo proposto vir a se realizar. Além disso, sempre haverá aqueles que segundo as normas estarão ilícitos e, mesmo que sujeitos a suas sanções, podem delas escapar. Por outro lado, como apontado por Boввı (1999), a norma jurídica não é boa em si mesma, mas enquanto condição para se atingir determinado fim: nesse sentido, a sociedade é incapaz de afastar os riscos resultantes da formulação espacial calcada nas arbitrariedades dos interesses particulares, irresponsáveis ou escusos, ou, pior ainda, que é resultado acidental, seja por falta de técnica ou de projeto de cidade e sociabilidade urbana por parte de seus propositores ou legitimadores. Assim, as diretrizes, determinações e parâmetros de uma ou mais normas urbanísticas podem criar um espaço normativo que não seja adequado, justo e equânime, que ignore o direito à cidade e renove as assimetrias de poder, que perpetue a desigualdade ou induza processos nocivos ao ambiente urbano e seus habitantes e, por isso, não seja desejoso por todos ou por uma grande maioria se efetivar.

\section{O PEU das Vargens, a Baixada de Jacarepaguá e a produção de riscos}

Propomos analisar o PEU das Vargens a partir dos enfoques até agora apresentados. Trata-se de uma lei que pode e deve ser compreendida nesta relação entre as imprecisões e riscos próprios das normas urbanísticas, do processo de urbanização e da modernidade. É o que faremos a seguir, a partir de uma análise dos riscos nas dimensões jurídico-política, urbano-arquitetônica e geobiofísica.

\section{Os riscos na dimensão jurídico-política}

Apesar do crescimento econômico e da cada vez maior projeção no cenário internacional, o Brasil permanece com grande parte de suas mazelas sociais, sendo suas cidades o maior reflexo destes problemas. Além do enorme déficit habitacional e de infraestrutura, especialmente de saneamento básico, as cidades brasileiras mantêmse resultantes da apropriação do solo urbano para maisvalias fundiárias, da constituição de "bancos de terras" subutilizadas, de políticas clientelistas, assistencialistas e mantenedoras de privilégios e das ocupações de áreas ambientalmente frágeis por todas as classes sociais. A despeito de um enorme contraste entre o espaço normativo e a cidade real, tais fatos foram historicamente acompanhados de intervenções do poder público sob a modalidade de criação de novos ou perpetuação de velhos instrumentos urbanísticos de planejamento que, sob o manto da "estratégia da ordem", realimentaram processos de exclusão social.

Estas contradições entre a intencionalidade contida nas normas jurídicas e as necessidades de transformações urbanas e sociais, continuamente dificultadas, ganharam um contraponto na Constituição Federal de 1988, em vigor: inspirados pela ação do Movimento Nacional pela Reforma Urbana (MNRU) e incluídos a partir de uma emenda de iniciativa popular, o artigo 182 determina que a política urbana deve ordenar o pleno desenvolvimento da função social da cidade e da propriedade urbana e garantir o bem-estar de seus habitantes (características 
que dependem também do equilíbrio dos ecossistemas, nos termos definidos pelo artigo 225 da mesma carta política) e indica o plano diretor como instrumento básico da política de desenvolvimento e expansão urbana, obrigatório para municípios com mais de 20.000 habitantes.

O termo Reforma Urbana é muito antigo, sendo comumente associado a reformas como as de Pereira Passos, de intervenções autoritárias e de conteúdo antipopular. Segundo SouzA (2002, p. 155-156), seu significado progressista, gestado pela esquerda brasileira, foi evidenciado só na década de 1960, a partir de projeto do governo do presidente João Goulart (1961-1964) e de um encontro realizado na cidade fluminense de Petrópolis, em 1963, que se tornou um marco ideológico do planejamento brasileiro por reunir políticos, técnicos e intelectuais em torno do tema da habitação. A ditadura militar que logo se seguiu, porém, além de tutelar 0 planejamento urbano à esfera federal, tornou-se grave entrave ao desenvolvimento de quaisquer reivindicações populares. Somente em meados da década de 1980, no contexto de abertura política iniciada por Ernesto Geisel, surge o Movimento Nacional pela Reforma Urbana (MNRU), unindo forças de vários movimentos sociais.

No momento da Assembléia Constituinte, o Congresso Nacional ofereceu a possibilidade de elaboração e encaminhamento, pela sociedade civil, de emendas populares, visando à inclusão ou alteração de textos no que viria a ser a nova Constituição Federal. O MNRU e seus aliados elaboraram uma emenda relativa à Reforma Urbana que obteve a adesão de 130.000 assinaturas de eleitores brasileiros, quando o mínimo necessário era 30.000 (SOUZA, op. cit., p. 159). O que restou dela está no já referido artigo 182 e no artigo 183, que institui o instrumento do usucapião urbano.

Tais artigos só foram regulamentados treze anos depois, pela Lei Federal o 10.257/ 2001, o Estatuto da Cidade, que disciplina as diretrizes da política urbana. Trata-se de um marco da normatização urbanística no Brasil, não só pelo Estatuto se constituir como veículo para se regular relações jurídicas e resguardar interesses, mas, principalmente, por incitar relações jurídico-sociais que possam vir a efetivar a própria eficácia da norma, legitimada pela sua capacidade de garantir os direitos da coletividade. O Estatuto também reforça a obrigatoriedade do plano diretor, que apesar de ser instrumento jurídico de Ionguíssima e controversa trajetória na história do planejamento urbano brasileiro (REzEnde, 1982), foi revisto conceitualmente, sobretudo pela sua transformação de instrumento considerado autoritário para instrumento democrático, agora com obrigatória participação popular na produção de seu texto legislativo (GoNDIM, 1991; Ribeiro \& Cardoso, 1990).
Além disso, foram legitimados, através do Estatuto, instrumentos de política urbana, que há muito vinham tentando ser implementados em algumas cidades, encontrando entraves legais, cujo intuito explícito é possibilitar que os municípios atuem efetivamente contra a retenção especulativa dos imóveis urbanos, a deterioração das áreas urbanizadas ou a degradação ambiental, sempre tendo em vista a participação popular e a instauração de mecanismos de controle social. Diante da conectividade existente entre à sadia qualidade de vida, a participação popular e o meio ambiente, o Estatuto da Cidade também representou, portanto, um avanço no que diz respeito às questões ambientais, pois as considera como fato crucial para a qualidade das cidades, fazendo uma direta relação entre a distribuição espacial da população e as atividades urbanas no território municipal com os efeitos sobre 0 ambiente. A proteção, preservação e recuperação do patrimônio ambiental, considerando-se tanto os bens naturais quanto os construídos, tornam-se, assim, temas fundamentais da política urbana e, consequentemente, da legislação urbana, incluindo, além do Plano Diretor, as leis dele derivadas como o são os projetos de estruturação urbana, inclusive o PEU das Vargens, que a ele devem se submeter por ser instrumento jurídico de hierarquia superior às demais leis urbanísticas.

Por essencialmente serem leis de zoneamento, uso e ocupação do solo para as áreas que abrangem, inclusive com determinação de parâmetros urbanísticos, os Proj etos de Estruturação Urbana (PEUs) devem se adequar aos princípios e diretrizes do Estatuto da Cidade, ainda que tenham sido propostos pela administração carioca já em 1977, no corpo do Plano Urbanístico Básico da Cidade do Rio de J aneiro (PUB-Rio), e que efetivamente poucos tenham sido elaborados e aprovados nos últimos vinte anos. No caso da área da Baixada de Jacarepaguá, já havia sido promulgado projeto de estruturação anterior, sob a forma da Lei Complementar no 79 , de 30 de maio de 2006, mas que por questões políticas jamais chegou a ser aplicado. A existência desta norma anterior acabou sendo utilizada como justificativa, apresentada pelo Poder Executivo Municipal, para que o Projeto de Lei Complementar no 33/09 tenha sido apresentado, votado, vetado, publicado e promulgado como a Lei Complementar 104/09, tornando-se o novo PEU das Vargens, em prazo recorde e sem discussão alguma, o que fere o inciso II, do artigo 10, do Estatuto da Cidade, combinado com os artigos 73 e 105, do atual Plano Diretor Decenal da Cidade do Rio de J aneiro (Lei Complementar no 16, de 4 de junho de 1992), que inclusive se encontra em processo de revisão.

Dentre os inúmeros problemas apresentados no texto legal, ainda que este novo PEU das Vargens possua artigos iniciais referindo-se ao Estatuto da Cidade, à função social e às prerrogativas ambientais referidas 
pelo mesmo, na análise do restante dos artigos e de seus anexos - sobretudo o Anexo $V$, onde se escondem seus parâmetros urbanísticos - o princípio da justa distribuição dos bônus e ônus do desenvolvimento urbano é ignorado: tais parâmetros são modificados sem que tenham sido apresentados estudos que comprovem a viabilidade do aumento generoso de potencial construtivo por eles proposto; e, apesar de haver aumento ainda mais significativo de potencial construtivo mediante contrapartida dos proprietários de terras, através do uso, bastante deturpado, do instrumento da outorga onerosa do direito de construir. Trata-se de instrumento da política urbana regulamentado pelo Estatuto da Cidade e originalmente criado com o intuito de se permitir adensamento acima do previsto em áreas já dotadas de infraestruturas e historicamente privilegiadas pelo poder público, mediante pagamento de contrapartida a ser utilizada em áreas que necessitem de investimento, sendo obrigatório que o plano diretor municipal indique as áreas passíveis de sua utilização (OLIVEIRA, 2001).

No caso do PEU das Vargens, o instrumento está sendo utilizado de forma inadequada, à medida que a área, mesmo que atualmente com baixa densidade, é notoriamente carente de infraestrutura básica. Ademais, mesmo sem ela já se tem garantida, a partir dos parâmetros básicos elevados, enormes maisvalias fundiárias. Além disso, a compra de potencial construtivo não é garantida no texto da lei: o mercado, se assim preferir, poderá adensar a área sem a utilização do instrumento da outorga, já que os índices básicos já são bastante generosos. E, no caso da compra deste potencial, também não é legalmente garantida a aplicação dos recursos oriundos da contrapartida na própria área.

O PEU das Vargens também afronta o Art. 2ํㅜㄹ inciso VI, alínea g, e incisosXII e XIII do Estatuto da Cidade por induzir e autorizar ocupação maciça da Baixada de J acarepaguá, área notoriamente considerada ambientalmente frágil. Além disso, não foi também atendido o condicionante de avaliação prévia das condições físicas adversas à ocupação urbana em baixadas, nos termos do artigo 50, do Plano Diretor Decenal, especialmente o parágrafo 4으, que estabelece que "as áreas frágeis de baixadas poderão comportar usos agrícolas, de lazer e residenciais de baixa densidade, condicionados estes à realização de obras de macrodrenagem e à redefinição de cotas de soleira das edificações".

Diante do que foi até agora exposto, não seria leviano dizer que caso o novo PEU das Vargens permaneça vigente há claros riscos no campo jurídico-político, sobretudo o de fazer-se letra morta todo o processo de construção da gestão democrática da cidade que é fruto de discussões político-sociais que possuem mais de quarenta anos e que se legitimaram através da Constituição Federal, do Estatuto da Cidade e, no caso do Rio de J aneiro, do seu inovador Plano Diretor Decenal. Além de esta situação poder vir a incentivar o sentimento de descrédito na eficácia normativa na sua efetiva capacidade de reconduzir o ordenamento territorial urbano através do processo democrático, mas ainda se abre perigoso precedente para abertamente se gerir a cidade de forma arbitrária, através de interesses pontuais e particulares escamoteados em falsos discursos sobre grandes projetos e megaeventos de suposto interesse coletivo, como as Olimpíadas, em que se propagam determinadas certezas sobre determinados futuros, fazendo-se com que os fins passem a justificar os meios.

\section{Os riscos na dimensão urbano-arquitetônica}

Complementarmente ao que foi discutido na seção anterior, deve-se atentar que mudanças na legislação urbanística, como as propostas pelo PEU das Vargens, trazem consigo um modelo de ocupação do território, de dimensão arquitetônica e urbanística, que pode ser predatório quando ignora as condições ambientais da área de implantação e sua capacidade de suporte. Faz-se necessário, por isso, direcionar atenção à relação entre o aumento de densidade urbana, provocado por estas mudanças nas normas, o que resulta, minimamente, em aumento evidente de necessidade de provisão de infraestrutura para o saneamento básico (abastecimento de água, esgoto, resíduos sólidos e drenagem urbana) e o impacto sobre a paisagem existente mediante a inserção de novas morfologias.

A densidade urbana é, segundo Acioly \& Davidson (1998), um dos componentes mais importantes do planejamento das cidades. Dentre muitos fatores que à densidade se associam, há que se considerar, por um lado, que um espraiamento da urbanização gerará custos elevados de implantação de infraestrutura (pavimentação, redes, transporte) e enormes deslocamentos da população (que geram gasto energético e potencial de poluição e engarrafamentos, via maior necessidade de deslocamento individual motorizado ou por transportes públicos). Mas a densidade habitacional, maior contribuição de área construída nas cidades, tem também direta relação com a impermeabilização do solo, que por sua vez tem impacto direto sobre a drenagem das águas. Além disso, maiores populações fazem surgir mais automóveis nas ruas; Iançam mais esgoto sobre os corpos hídricos, demandando mais e melhores tratamentos de águas residuárias e, consequentemente, mais gasto energético; consomem mais água, necessitando mais captação de água dos mananciais à montante; e geram mais resíduos sólidos, que geram mais tráfego, via caminhões de coleta, demandam área de aterro sanitário e, potencialmente, 
geram poluição difusa, através de resíduos arrastados pelas águas de chuva, entupindo as redes de esgotos e drenagem, chegando inclusive aos corpos hídricos.

Em outras palavras, deve-se considerar, de forma integrada e indissociável, tanto as medidas estruturais (intervenções físicas) quanto as medidas não estruturais (demais intervenções) que são parte do processo de planejamento urbano e ambiental: a gestão das águas municipais - no que diz respeito à captação, à emissão de efluentes (águas residuárias), ao controle da contaminação de mananciais, à macrodrenagem, à microdrenagem, ao abastecimento de água e à eficiência e à fiscalização de todos estes serviços; o gerenciamento integrado de resíduos sólidos; a legislação do uso do solo (incluindo as ocupações irregulares de faixas marginais de rios e lagoas, que contribuem para as inundações); a necessidade de provisão do déficit habitacional em diversas áreas da cidade; e, por fim, a adoção de tecnologias limpas e soluções eficientes nos lotes urbanos e nas próprias edificações (BARROS, 2005; TucCl, 2005)

Estudo recente (Name, 2010) realizou cálculo baseado nos parâmetros urbanísticos presentes no recémaprovado PEU das Vargens - taxa de ocupação (relação entre a projeção horizontal da edificação e o tamanho do terreno, expressa em percentagem), taxa de permeabilidade (porcentagem do terreno que a legislação sujeita a estar livre de pavimentação), índice de aproveitamento do terreno (o IAT, que é a relação entre o tamanho do terreno e a área total construída da edificação), lote mínimo e percentual de doação de terras à municipalidade -, espacializandoos (Figs. 7 a 9) e tendo por obj etivo se chegar a valores aproximados da demanda por infraestrutura urbana que uma ocupação que utilizasse todo o potencial construtivo possível na lei necessitaria: para isto, considerou-se neste cenário proposto que, sempre que a lei permitisse, utilizar-se-ia o mecanismo da outorga para ganho de potencial construtivo e que sempre se realizariam parcelamentos que doassem 0 mínimo de terras previsto na lei para transformação em áreas públicas. Além disso, foram utilizados: dados per capta do SNIS/ IBGE (2007) para consumo de água e necessidade de coleta de esgoto; dados per capta para coleta de resíduos sólidos domiciliares da Prefeitura da Cidade do Rio de Janeiro (2005); 0 valor de 3,5 pessoas por família brasileira fornecido pelo IBGE; e, por fim, certos descontos para utilização de solo urbano para áreas não-residenciais e outros referentes a áreas de uso comum ou de circulação no interior das edificações. 0 resultado deste cálculo bastante simples (TABELA I), é alarmante, desenhando um potencial de risco bastante expressivo gerado pela ocupação prescrita na lei.

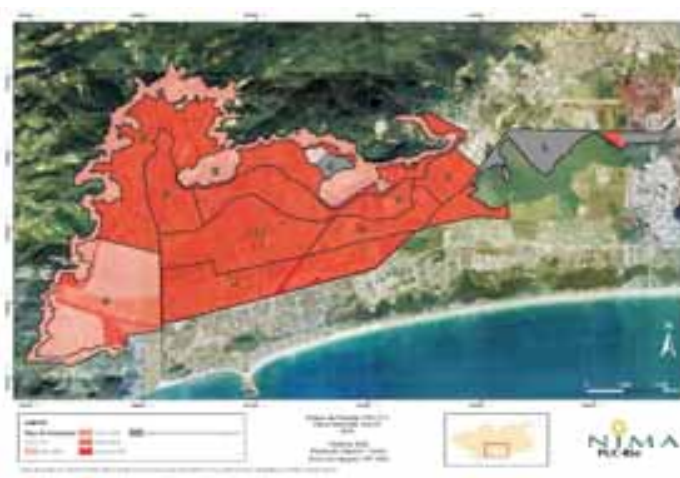

Fig. 7 - Taxa de Ocupação, por Setor do PEU das Vargens. Fonte: NIMA (2009)

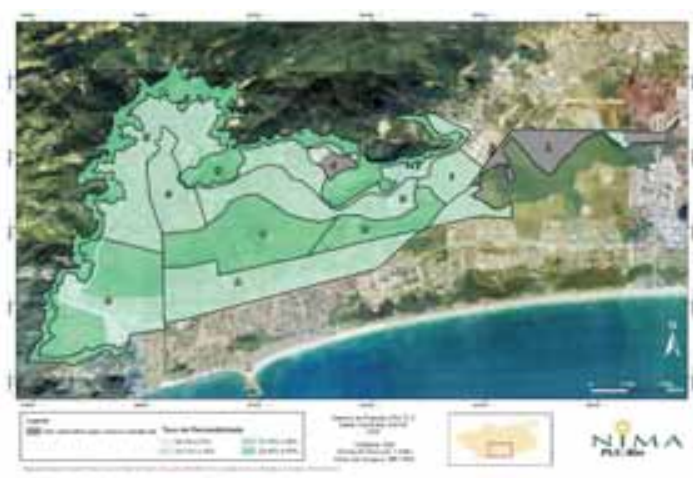

Fig. 8 - Taxa de Permeabilidade, por Setor do PEU das Vargens. Fonte: NIMA (2009)

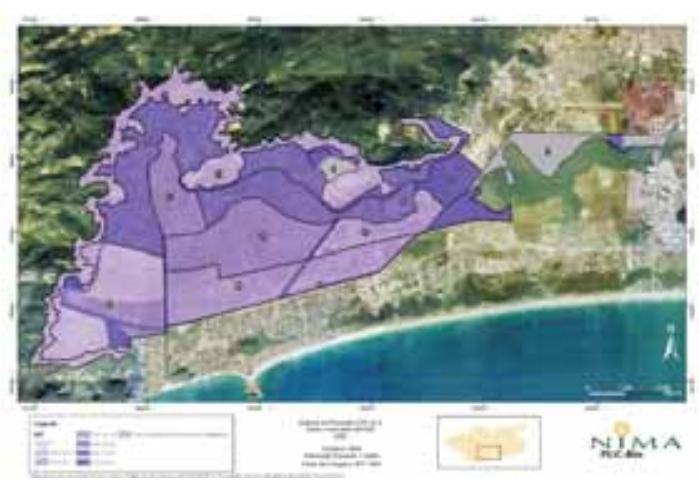

Fig. 9 - Índice de Aproveitamento do Terreno, por Setor do PEU das Vargens. Fonte: NIMA (2009)

O cenário apresentado também foi espacializado (Figs. 10 a 14) e revela espectro de impactos altos sobre a área. Desse modo, ainda que se trate de uma projeção de uma realização total do potencial construtivo, ele está previsto em lei, e portanto não pode ser descartado. Afinal de contas, bairros cariocas como Copacabana, Catete e o Centro são exemplos presentes de ocupação que ao longo do tempo realizou praticamente $100 \%$ de suas possibilidades de adensamento. 
RISCOS - Associação Portuguesa de Riscos, Prevenção e Segurança

TABELA I: Síntese da Proj eção de Máximo Potencial Construtivo, População e Demanda por Infraestrutura - área do PEU das Vargens

\begin{tabular}{|c|c|c|c|c|c|c|c|c|}
\hline $\begin{array}{l}\text { área passível } \\
\text { a edificação } \\
\text { para uso } \\
\text { residencial } \\
\left(\mathrm{m}^{2}\right)\end{array}$ & $\begin{array}{c}\text { superfície } \\
\text { da área } \\
\text { total } \\
\text { ocupada }\end{array}$ & $\begin{array}{c}\text { potencial } \\
\text { construtivo } \\
\left(\mathrm{m}^{2}\right)\end{array}$ & $\begin{array}{c}\text { projeção da } \\
\text { população } \\
\text { (hab) }\end{array}$ & $\begin{array}{c}\text { densidade } \\
\text { bruta } \\
\text { (hab/ha) }\end{array}$ & $\begin{array}{l}\text { densidade } \\
\text { líquida } \\
\text { (hab/ha) }\end{array}$ & $\begin{array}{l}\text { consumo } \\
\text { de água } \\
\text { (m³/dia) }\end{array}$ & $\begin{array}{l}\text { esgoto a } \\
\text { coletar } \\
\text { (m³/dia) }\end{array}$ & $\begin{array}{c}\text { resíduos } \\
\text { sólidos } \\
\text { domésticos a } \\
\text { coletar (ton/ } \\
\text { dia) }\end{array}$ \\
\hline 33.616 .047 & $62,98 \%$ & 60.336 .360 & 1.410 .891 & 264,32 & 419,71 & 334.240 & 335.369 & 927 \\
\hline
\end{tabular}

Fonte: NAME (2010)

Nesse sentido, vale a pena fazer algumas comparações entre os dados projetados e os dados efetivos de bairros da cidade. Relatório da Secretaria Municipal de Urbanismo (PCRJ , 2006), órgão da prefeitura, que reúne dadose indica diretrizes para a revisão do Plano Diretor Decenal, aponta que, no que diz respeito à densidade demográfica (bruta), em 2000, poucos bairros ultrapassavam o limite de 200 hab/ ha. Além disso, os bairros abrangidos pelo PEU das Vargens também possuíam, em 2000, densidades bastante baixas, inferiores a $50 \mathrm{hab} / \mathrm{ha}$. Mesmo que estes dados da SMU sejam antigos, o mesmo relatório apontou que o crescimento populacional na cidade, no período anterior de dez anos (1991-2000), fora inferior a 6\%(seis por cento). Assim, é possível considerar não ter havido mudanças tão significativas na população da área. 0 mesmo relatório da SMU, diante de fragilidades ambientais e infraestruturais pré-existentes apresentadas ao longo do documento, recomenda para os bairros do Recreio dos Bandeirantes, Camorim, Vargem Grande e Vargem Pequena os seguintes índices de aproveitamento do terreno: 1,5 para o Recreio, Camorim, Vargem Pequena e as áreas situadas ao longo do eixo da avenida das Américas; e 1 para Vargem Grande. Tratam-se de valores já assim definidos no Plano Diretor Decenal, de 1992, muito abaixo dos que acabaram sendo utilizados no PEU das Vargens.

Ao se voltar aos cálculos apresentados e considerar os valores conseguidos por cada zona de cada setor do PEU das Vargens, aqui também espacializados, notarse-ão situações extremamente críticas: nas projeções para alagumas das Zonas de Uso Multifamiliar (as ZUM 3) localizadas dentro dos setores $A, B, G, I$, J e L, por exemplo, chega-se a densidades de 535,50 hab/ha e 840 hab/ ha (ver Figs. 10 e 11), respectivamente bruta e líquida. São densidades próximas as das cidades mais densas da Ásia, onde a densidade líquida é acima de 900 hab/ha (Acioly \& Davidson, op. cit.). Também são valores acima do limite de saturação indicado pela SMU no já referido relatório de revisão do Plano Diretor, estipulado em 500 hab/ ha, número, aliás, bem acima da média das cidades latino-americanas. São, por fim, também marcas superiores as dos dois bairros com maior densidade do Rio de Janeiro, que são Catete e Copacabana: eles apresentavam, em 2000, valores brutos de 422, 3 hab/ ha e $389,50 \mathrm{hab} / \mathrm{ha}$, respectivamente. Neste sentido, cabe assinalar que especificamente a ZUM 3 do Setor A possui 57,23 ha, área um pouco menor que a do bairro

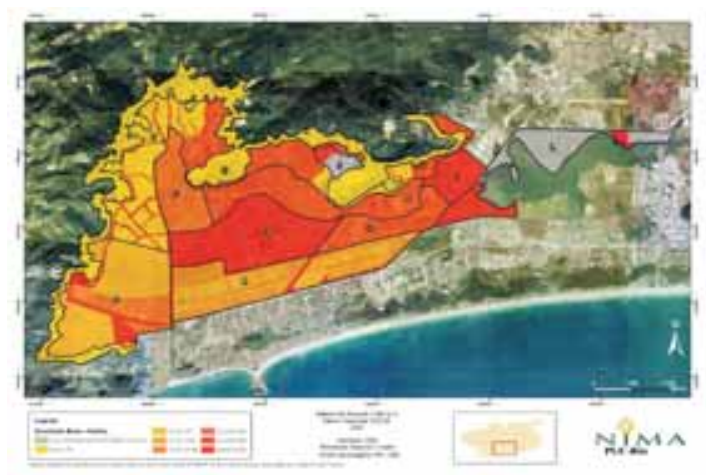

Fig. 10 - Densidade Bruta (ha/ha), por Setor do PEU das Vargens. Fonte: NIMA (2009)

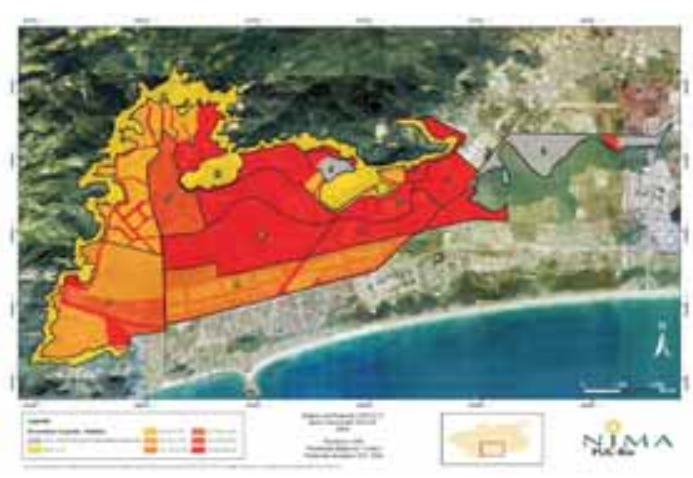

Fig. 11 -Densidade Líquida (ha/ha), por Setor do PEU das Vargens. Fonte: NIMA (2009)

do Catete, que é de 68,10 ha. Em outras palavras, a ZUM 3 do Setor A é um bairro um pouco menor e muito mais denso que o bairro de maior densidade da cidade. Há um Catete dentro do Setor A do PEU das Vargens. $\mathrm{E}$ as demais ZUM 3 deste mesmo setor têm áreas ainda menores, com a mesma densidade. A demanda por infraestrutura é, portanto, altíssima, e a eminência de não-atendimento é um sério risco de agravamento de problemas já existentes de saneamento, sobretudo para as populações de baixa renda.

Cumpre destacar, por fim, algumas observações sobre o Setor $L$, que abrange uma zona em que se localiza parte das instalações para as Olimpíadas de 2016 (Fig. 15) e outras, como as ZUM 2 e 3, as quais se destinam o uso residencial multifamiliar. Na legislação anteriormente vigente, não eram permitidos em nenhuma destas áreas o parcelamento e a edifcação, sendo classificadas como áreas non aedificandi. Embora não sejam 


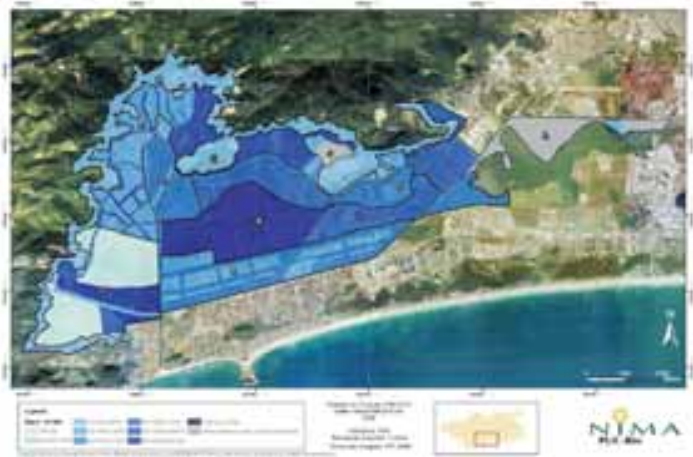

Fig. 12 -Consumo de Água ( $\left.\mathrm{m}^{3} / \mathrm{dia}\right)$, por Setor do PEU das Vargens. Fonte: NIMA (2009)

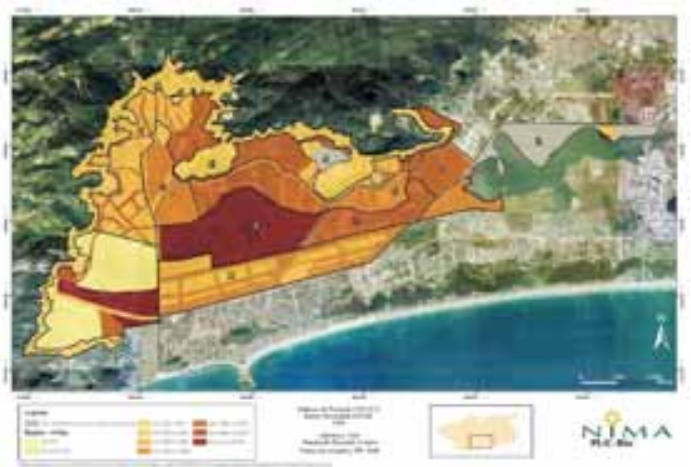

Fig. 13 - Esgoto a Coletar $\left(\mathrm{m}^{3} / \mathrm{dia}\right)$, por Setor do PEU das Vargens. Fonte: NIMA (2009)

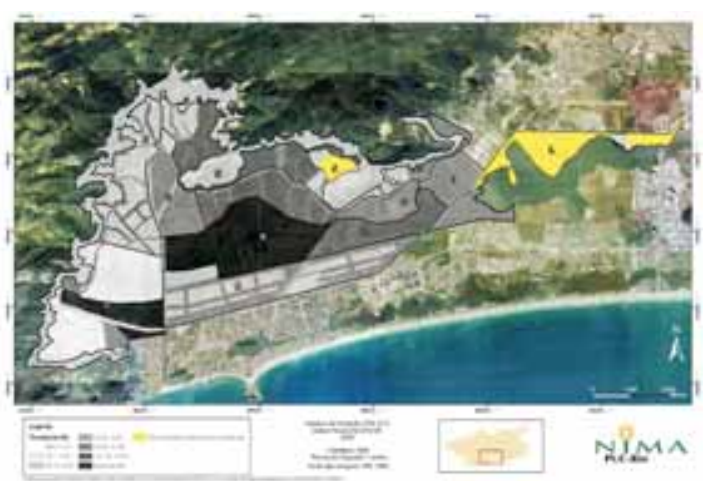

Fig. 14 - Resíduos Sólidos Domésticos a Coletar (ton/ dia), por Setor do PEU das Vargens. Fonte: NIMA (2009)

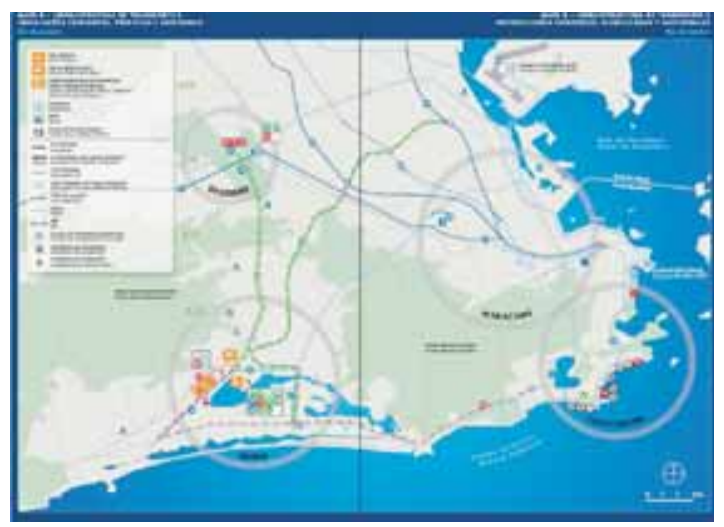

Fig. 15 - Regiões para instalação de equipamentos e infraestruturas para a Rio 2016. Fonte: www.rio2016.com.br especificados parâmetros para a área abrangida pelo projeto de ocupação para as Olimpíadas, o documento apresentado ao Comitê Olímpico Internacional mostra uma ocupação contundente para a Vila de Mídia e a Vila Olímpica (Fig. 16), que provavelmente serão depois ocupadas permanentemente por famílias cariocas, que comprarão as unidades residenciais previstas. Já as ZUM 2 e 3 se converteram na nova lei a áreas com parâmetros extremamente generosos que podem chegar, mediante uso do mecanismo da outorga, a um IAT de valor igual a 3, com $50 \%$ de taxa de ocupação e apenas $30 \%$ de taxa de permeabilidade. As Figs. 17 a 20, subsequentes, exemplificam esquematicamente algumas transformações possíveis da paisagem local e sua ambiência a partir da utilização destes parâmetros.

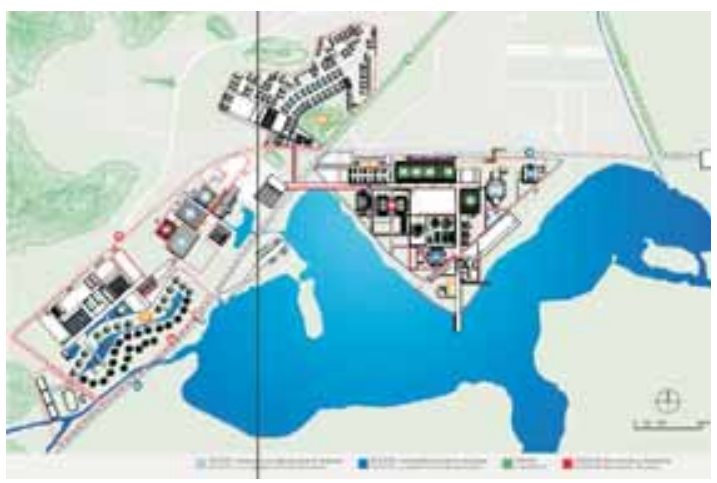

Fig. 16 - "Região Barra" do projeto apresentado ao COI para a Rio 2016. Na área do autódromo, junto à Lapa, se instalarão os principais edifícios de cunho esportivo. A noroeste, a Vila Mídia,

e a Oeste, a Vila Olímpica. Fonte: www.rio2016.com.br
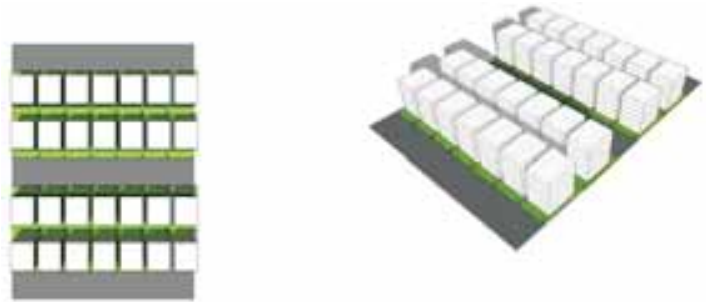

Fig. 17 - Na ZUM 2 do Setor L permite-se parcelamentos com lotes de $360 \mathrm{~m}^{2}$. As figuras acima mostram esquematicamente, para área próxima a 1 hectare, a planta de situação e a perspectiva relacionadas à utilização da taxa de ocupação máxima de $50 \%$ Desse maneira, atinge-se o limite 6 pavimentos para a utilização do IAT =3. Fonte: NAME, 2010.
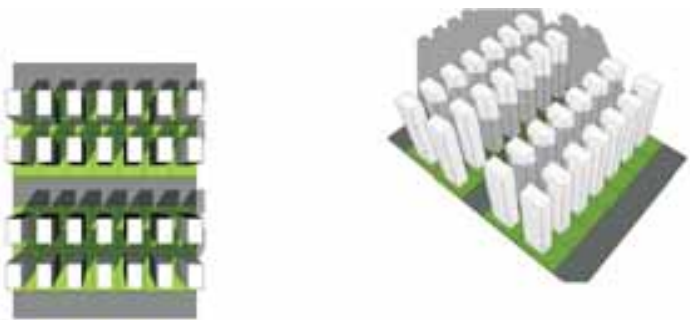

Fig. 18 - Na mesma ZUM 2, em uma situação em que o empreendimento queira atingir os 15 pavimentos previstos no PEU das vargens como máximo permitido, o IAT $=3$ será atingido mediante taxa de ocupação de $20 \%$ o que pode ser inviável em lotes pequenos, mas torna-se economicamente vantajoso para os proprietários de lotes maiores, o que induz o modelo de condomínios fechados. Fonte: Name, 2010. 

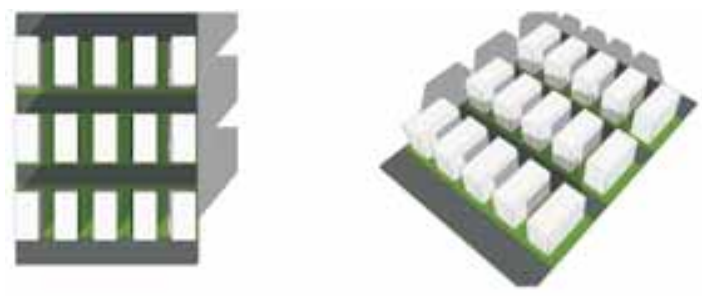

Fig. 19 - Na ZUM 3, o lote mínimo é de $600 \mathrm{~m}^{2}$. Para se atingir o $\mid A T=3$, e a máxima taxa de ocupação prevista, de $50 \%$ atinge-se gabarito de 6 pavimentos.
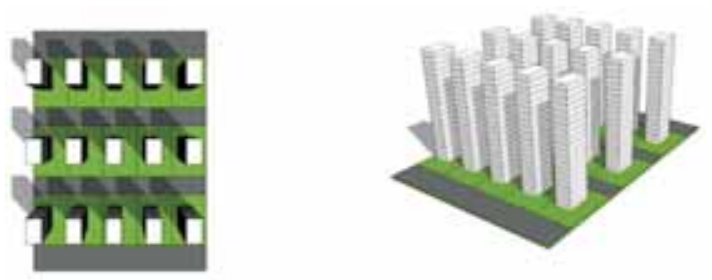

Fig. 20 - Na mesma zona, para se atingir o maior IAT e o gabarito máximo de 18 pavimentos, oacupa-se apenas $17 \%$ situação que também só se torna atraente para o propritário quanto maior o lote ou gleba, induzindo-se assim o modelo de condomínios fechados.

Diante dos cálculos e esquemas apresentados, podese dizer que, através da lei, o entorno da área onde estão previstas as edificações para as Olimpíadas tem legitimação para a produção de mais-valias fundiárias e da especulação imobiliária. Sob o pretexto da inserção de equipamentos olímpicos oferecidos discursivamente como bem coletivo, provavelmente se promoverá nova centralidade urbana, a gerar ganhos econômicos para alguns, às custas de uma mudança significativa da paisagem e de seus usos, o que onera e torna ainda mais problemático o saneamento ambiental da área e põe em risco os componentes geobiofísicos dos seus ecossistemas.

\section{Os riscos na dimensão dos processos geobiofísicos}

As zonas costeiras constituem ambientes de transição continente-oceano, sendo afetadas por processos continentais e marinhos e, por isso, desenvolvendo aspectos sedimentares distintos, conforme a predominância de um ou de outro. Nestas zonas estão caracterizados os ambientes de mais alta energia e de maiores taxas de sedimentação ou erosão da margem continental (DIAS \& SILVA, 1984). A vegetação das planícies costeiras brasileiras é bastante heterogênea tanto em termos estruturais quanto em relação à diversidade florística, o que resulta em uma paisagem em mosaico e, portanto, com alta diversidade em termos de variabilidade de ecossistemas. Os processos de deposição da areia pelo mar, as tempestades, as correntes litorâneas e os ventos constituem os mecanismos físicos próprios dos sistemas costeiros e que são os responsáveis pela modelação natural do relevo. Tais mecanismos contribuem, portanto, para o surgimento e manutenção dos ecossistemas das baixadas litorâneas.

Na área do PEU das Vargens, o maciço da Pedra Branca e o maciço da Tijuca, respectivamente com 1.024 e 1.021 metros de altitude máxima, formam os divisores do sistema hidrográfico da Baixada, cujos rios deságuam nas lagunas costeiras de J acarepaguá, Tijuca, Camorim (ligação entre a lagoa de Jacarepaguá e da Tijuca), Marapendi e Lagoinha. Ao sul, sua orla marítima possui uma extensão de 21 quilômetros. Os rios que drenam a área da Baixada descem dos maciços atingindo, em alguns casos, altitudes superiores a 1.000 metros, com mudanças bruscas de declividade ao atingirem a planície. Este fato leva a um intenso processo de erosão das encostas e ao carreamento de material sólido para os cursos d'água, agravado pelo processo de erosão antrópica, o que sujeita a área a constantes enchentes, principalmente na região de Jacarepaguá e no entorno das lagunas. Estudos em desenvolvimento na área apontam que as copas das árvores de matas bem preservadas da encosta chegam a interceptar cerca de 70 a $90 \%$ da chuva incidente, retendo grande parte da umidade. Uma vez dentro do solo, a água que não foi absorvida pela vegetação ou evapotranspirada escoa sub-superficialmente e superficialmente. Caso o solo já esteja saturado, pode ocorrer o fluxo superficial de saturação, alcançando os canais que a levará para as lagoas. Neste ciclo sobre sistemas montanhosos, portanto, o papel da vegetação é crítico, tanto no que se refere à sua biomassa aérea (folhas, galhos e troncos que interceptam, amortecem e redistribuem a chuva) e na serrapilheira que protege, armazena e redistribui a água que atinge o piso florestal, como na subterrânea as raízes que estruturam e "ancoram" os solos declivosos (Montezuma \& Oliveira, 2010).

Na planície, devido à proximidade do lençol freático e à rede dentrítica de drenagem, havia o predomínio da floresta ombrófila densa de terras baixas ou mata paludosa de planície, caracterizada pelo solo orgânico tipo turfa, periodicamente ou permanentemente encharcado de água doce, ocupando as planícies fluvio-lacustres, sem influência das marés, sendo sua espécie característica a Tabebuia cassinoides, (pau-detamanco, usado no fabrico de ferramentas e utensílios agrícolas). Este tipo de floresta praticamente não é mais encontrado, restando poucos remanescentes no entorno das lagoas do Camorim, Tijuca e J acarepaguá. Nas margens das lagoas e canais (também denominadas matas riparianas), sem influência marinha, ocorrem vastos banhados, ou brejos, que se estendem ao lado da mata paludosa. Nestes predominam a taboa (Thypha sp.), acompanhada de uma riquíssima fauna de mamíferos, aves, anfíbios e répteis, incluindo nesta categoria o jacaré-de-papo-amarelo (Cayman latirostris), ameaçado de extinção pela caça e poluição das lagoas. Estas áreas 
têm um papel fundamental na preservação de espécies em escala global, uma vez que são áreas naturais de pousio de aves migratórias que as têm como rota e fonte de alimento e habitat durante os invernos rigorosos do hemisfério norte.

Na parte sul, entre a avenida das Américas e o oceano Atlântico, ocorre mosaico vegetacional de diversas tipologias de restinga, que de um modo geral são duplas, compostas por dois corpos arenosos paralelos. Dada a extensão da planície de Jacarepaguá, os depósitos arenosos ali presentes possibilitaram a ocorrência de vários ecossistemas do complexo de restinga, os quais variaram de campos ralos de gramíneas às matas fechadas de até 12 metros de altura ou brejos com densa vegetação aquática. Esses ecossistemas são cobertos por comunidades vegetais características que vão desde 0 tipo herbáceo ao arbustivo, formando moitas densas, intercaladas por espaços de vegetação esparsa, deixando aparecer a areia branca. A fixação do substrato arenoso pela cobertura vegetal das restingas, evita os problemas de erosão causada pelo vento, atenuando o assoreamento das lagoas e canais, contribuindo para a manutenção da permeabilidade do substrato e permitindo que as águas das chuvas alimentem o lençol freático, cujo nível garante a manutenção dos corpos d'água da região. Esta formação dá origem, muitas vezes, a sistemas de cordões intercalados por depressões que podem ser ocupadas por longas e estreitas lagoas ou por extensos brejos.

Nas áreas onde os solos estão sujeitos à saturação hídrica durante praticamente todo o tempo, mesmo nos períodos menos chuvosos, é possível a ocorrência de dois tipos de ecossistemas: os manguezais, normalmente onde há gradações para áreas mais salinas e formações arbóreas e arbustivas nos locais com substrato arenoso de melhor drenagem. A vegetação de mangue ocorre em trechos ao longo das lagoas e é composta principalmente pelo mangue vermelho (Rizhophora mangle), que é predominante, o mangue branco (Laguncularia racemosa) e o mangue siriúba (Avicennia sp), em áreas de menor salinidade.

Dado o processo histórico de ocupação do município do Rio de J aneiro, a Baixada de J acarepaguá é a única área do município que ainda abriga alguns remanescentes dos ecossistemas próprios dessas áreas: florestas ombrófila densa submontana (Mata Atlântica) nas vertentes das serras, nos morrotes e planos bem drenados, a floresta ombrófila densa de terras baixas, as áreas de formação pioneira com a floresta de restinga, e os cordões arenosos à beira do mar e o mangue, exclusivo dos solos litorâneos pantanosos, sujeitos à influência das marés. As florestas presentes nos dois maciços abrigam grande diversidade de espécies, sobretudo florística. Apesar de ainda não existir um levantamento completo da vegetação de ambos, as informações existentes apontam para a presença de várias espécies raras da Mata Atlântica, algumas das quais ameaçadas de extinção (Montezuma et. al., 2005; OLIVEIRA, 2005).

Do ponto de vista da biodiversidade, cada um dos ecossistemas que formam o mosaico da paisagem abriga um conjunto de espécies que possui um valor intrínseco de existência, além de valores estéticos, paisagísticos (Clusia sp., palmeiras), artesanais (Typha sp. usada na confecção de cestos, esteiras, etc.), alimentícios (araçá, pitanga, murici), medicinais (espécies de Clusia spp. vêm sendo estudada pela Fundação Oswaldo Cruz no controle de doenças cancerígenas) e ritualísticos para diversas religiões (figueiras, p.ex., são consideradas espécies sagradas). No que diz respeito especificamente à função ecossistêmica, ou seja, à relação das espécies entre si e destas com os locais onde ocorrem, tem-se a regulação de um conjunto de processos fundamentais tanto para a sobrevivência do mosaico natural como para as suas ocupações humanas. Exemplo importante é o da regulação do ciclo hidrológico, que diz respeito à atenuação do impacto direto das chuvas e sua redistribuição no solo, rios e canais; contenção de encostas, controle de enchentes, amenização climática, além do valor e efeito estético.

Entretanto, a situação atual dos supracitados ecossistemas da Baixada de Jacarepaguá encontrase comprometida em duas escalas. Na primeira delas, a escala da paisagem, a diversidade de ecossistemas vem sendo reduzida em número e em área. Dada a geodiversidade da área, tais ecossistemas ocorrem naturalmente em fragmentos. Com a supressão da vegetação e a paulatina ocupação humana, associada aos equipamentos urbanos necessários ao estabelecimento desses grupos, grande parte desses fragmentos estão sendo suprimidos, restando atualmente poucos remanescentes, sobretudo na área focada no atual PEU das Vargens. Ali predominam os brejos, matas paludosas e florestas ombrófilas nas encostas do maciço da Pedra Branca.

Na escala dos ecossistemas, é preciso mencionar que com a redução das áreas e 0 isolamento aumentado pela presença de barreiras físicas antrópicas, como vias de acesso, estabelecimentos comerciais e residenciais, os habitats das espécies já têm sofrido diretamente com a perda de habitat e com a penetração de vetores de transformação, como poluição sonora, química, alteração de temperatura, evaporação mais alta e a consequente perda de umidade do ar e do solo.

No que diz respeito à condição de drenagem, problema frequente em todas as baixadas, o mosaico desempenha um papel fundamental na redistribuição e alocação da água nos períodos de maior aporte das chuvas. Na porção florestal que ocupa as encostas dos maciços costeiros, o grau de conservação da cobertura vegetal varia em maior 
infiltração favorecida pelas florestas mais desenvolvidas, até maior escoamento de águas superficiais levando à perda da fertilidade dos solos e à erosão. 0 material que é carreado nas encostas é depositado nas áreas planas. A velocidade, quantidade e qualidade desse material é uma consequência da declividade, amplitude de relevo, tipo de solo e forma da encosta.

Já nas áreas planas, as enchentes na zona de restingas nunca trazem transbordamentos catastróficos. A distribuição intercalada de faixas arenosas e lagunas faz com que as águas que infiltram no solo arenoso não o saturem, apenas o umedeçam, enquanto a parte da água infiltrada vai para o mar ou para as lagunas por vertedouros naturais. A maior porção, no entanto, fica ali e aos poucos mergulha no solo, percolando pelas areias, evapora com o aquecimento pelo sol, ou é transportada pelos ventos contínuos em direção às montanhas, onde precipita e recarrega os canais que ali afloram, drenando toda a bacia hidrográfica. A hidrografia das restingas tem, deste modo, a sua característica fundamental de séries indefinidas de pequenos charcos lineares que, longe de prejudicarem a região, providencialmente a beneficiam com a umidade parcial e permanente num deserto. A circulação é meramente temporária e a depender das grandes águas, que impedem uma esterilização total pelo dessecamento (Lamego, 2007).

Quanto aos brejos e as matas paludosas, que são ecossistemas típicos de áreas alagadas, e, portanto, adaptados às inundações, o efeito das enchentes não Ihes são prejudiciais. Ao contrário, suportam tanto acréscimo de volume d'água como de sedimentos, mesmo por períodos prolongados. Tais ecossistemas atuam no armazenamento dos fluxos que vêm dos maciços adjacentes, reduzindo o impacto da velocidade em que chegam, lembrando que quanto maior a amplitude do declive e quanto menor for a cobertura florestal das encostas, maior será o impacto do fluxo de sedimento e de água que chega à área plana adjacente. As áreas das Vargens Grande, Pequena e Recreio encontramse em grande parte sob esta condição. É lícito afirmar que a remoção dessas áreas implica em onerar 0 serviço público no que tange aos métodos de remoção e deposição do material que naturalmente aportam a essas áreas. Como estas são adjacentes às restingas, 0 excesso e a redistribuição são direcionados para esta porção arenosa, que por sua vez verte para as praias e o mar, podendo em alguns casos afetar sua balneabilidade.

Diante desta leitura geobiofísica da Baixada de Jacarepaguá, cabe dizer que a área correspondente ao PEU das Vargens abrange uma porção significativa, contendo três dos seus principais ecossistemas: floresta ombrófila densa submontana nos setores $\mathrm{H}$, que abrange os limites estabelecidos pelas cotas altimétricas entre 25 e 100 metros; os brejos e as florestas paludosas na planície costeira, os quais ocorrem nos setores $A, B$, $C, D, F, I, e ~ L$, ou seja a maior parte de toda a área do PEU Vargens ou 1.586 hectares de um total aproximado de 5.000 hectares. Assim sendo, o risco para as áreas úmidas é considerável, podendo haver impactos de grande magnitude.

Nesse sentido, pode-se dizer que dentre estes ecossistemas, é o brejo aquele que, hoje, devido a sua condição plana e por estar presente em grande parte da planície, encontra-se mais frágil, e que, diante da ocupação prevista pelo PEU das Vargens, tem-se sobre ele um preponderante fator adicional de risco: pois se as áreas de ocorrência de brejos em todo o município do Rio de Janeiro, até o ano e 1999, correspondiam a 4.859 hectares, $50 \%$ destes encontravam-se na área do referido PEU, cuja redução em 15 anos foi de 563 hectares (TABeLA II). Além disso, se por um lado este resultado demonstra que a expansão urbana tem se direcionado especificamente para os domínios dos brejos, por outro lado, considerando-se que para os setores $A, B, I$ e L localizam-se brejos e estão propostos índices urbanísticos que ultrapassam bastante 0 limite de saturação de 500 hab/ha, os brejos ali remanescentes têm claros riscos de supressão. Além disso, o grau de impermeabilização que será gerado nessas áreas naturalmente alagáveis, associado à tipologia do solo correspondente, ou seja, saturado, hidromórfico e bastante profundos (algumas vezes atingindo profundidades superiores a 20 metros), pode afetar áreas adjacentes, levando a extinção de fragmentos de brejos que possam permanecer, uma vez que a drenagem deficiente poderá afetar sua saturação.

TABELA II: Evolução da área úmida (brejos) segundo a classificação do Instituto Pereira Passos

\begin{tabular}{|c|c|c|c|c|}
\hline \multirow{2}{*}{ Ano } & \multicolumn{2}{|c|}{ Área $\left(\mathrm{km}^{2}\right)$} & \multicolumn{2}{c|}{ Área (ha) } \\
\cline { 2 - 5 } & $\begin{array}{c}\text { município } \\
\text { Rio de } \\
\text { J aneiro }\end{array}$ & $\begin{array}{c}\text { Área do } \\
\text { PEU }\end{array}$ & $\begin{array}{c}\text { município } \\
\text { Rio de } \\
\text { Janeiro }\end{array}$ & $\begin{array}{c}\text { Área do } \\
\text { PEU }\end{array}$ \\
\hline 1984 & 48,6 & 21,5 & 4859 & 2150 \\
\hline 1988 & 45,1 & 20,2 & 4508 & 2020 \\
\hline 1992 & 41,2 & 16,6 & 4118 & 1663 \\
\hline 1996 & 36,3 & 16,8 & 3629 & 1685 \\
\hline 1999 & 38,8 & 15,9 & 3884 & 1587 \\
\hline redução em & & & & \\
15 anos & 9,7 & 5,6 & 974 & 563 \\
\hline
\end{tabular}

Fonte: Instituto Pereira Passos, Prefeitura da Cidade do Rio de J aneiro (1999).

Quanto aos ecossistemas de florestas ombrófilas densas submontanas, o maior risco de impacto diz respeito à ocupação proposta para o setor H. Embora a lei determine uma ocupação unifamiliar, de densidade de $7 \mathrm{hab} / \mathrm{ha}$, com lotes de $5.000 \mathrm{~m}^{2}$, a localização limítrofe a uma unidade de conservação - o Parque Estadual da 
Pedra Branca - já em cota elevada - 100 metros - já vem gerando os chamados efeitos de borda. Característicos de aberturas em área de florestas ou vizinhas a estas, os efeitos de borda expõem as bordas florestais a novas condições microclimáticas, tais como a ação mais intensa de ventos, aumento da temperatura, redução da umidade relativa do ar por aumento da evaporação e aumento de luminosidade. A mudança dessas condições causa resposta da vegetação que, por estar mais adaptada à condição oposta (qual seja: maior umidade, menor luminosidade e temperatura, além de bloqueio da ação direta do vento) faz a mortalidade de árvores aumentar e se expandir para o interior da floresta, seja por inadequação ao ambiente microclimático ou pela ação mecânica, um efeito em cascata que em áreas de relevo montanhoso é ainda pouco conhecido.

Levando em consideração que o maciço da Pedra Branca é um mosaico vegetacional em diferentes graus de preservação, a probabilidade da degradação das florestas se propagarem para as zonas mais centrais e preservadas do maciço é significativa, sobretudo porque as áreas fronteiriças às estradas já estão sendo impactadas. Se tomarmos como exemplo a área do Camorim, a condição desta bacia já aponta para um possível efeito dominó que pode ocorrer nesta área em que hoje a densidade de ocupação é uma das mais baixas da cidade. Se na atual condição, o percentual de floresta em bom estado de conservação, que garante uma boa funcionalidade ecológica, já não é o dominante na paisagem do maciço, imagine-se o potencial de risco que o aumento expressivo da densidade populacional e da ocupação edilícia, apresentado na seção anterior, pode vir a causar.

\section{Conclusão}

Inexoravelmente ligado ao processo de produção das cidades brasileiras, particularmente ao da cidade do Rio de Janeiro historicamente indutor de impactos ambientais e reprodutor de iniquidades socioespaciais, o PEU das Vargens, recém-aprovado, parece ter como questões estruturais e focos de interesse, ao invés do ordenamento espacial, a arrecadação de fundos para a realização das Olimpíadas de 2016 e a produção de mais-valias fundiárias para o mercado imobiliário. Ademais, foi texto técnico apresentado e aprovado em tempo recorde, o que necessariamente provoca dúvidas, dada a complexidade da área a que se direciona, sobre sua precisa avaliação por parte dos vereadores que o aprovaram. Seu conteúdo jurídicopolítico, por sua vez, contrasta com outras normas que Ihe são superiores, resultantes de profundos debates da sociedade brasileira sobre os ônus do processo de urbanização. Seus parâmetros urbanísticos constroem espaço normativo permissivo, com modelo de ocupação de extensas áreas e altas densidades que até então eram alvo de restrição e sanção de legislações anterior, por serem direcionados a uma área notoriamente frágil e com funções ecossistêmicas relevantes.

Por tudo que foi apresentado, a nosso ver o PEU das Vargens, apesar de ato normativo pontual, legitima processos de ocupação sobre a Baixada de J acarepaguá que historicamente degradaram outras áreas da cidade do Rio de Janeiro. Neste sentido, é norma na qual o modelo de ocupação prescrito é espaço normativo que aponta para um futuro de feições distópicas, calcado em inúmeras possibilidades de risco. Listamos abaixo aquelas que podem ser compreendidas através da leitura de nosso trabalho, sem que estejam esgotadas outras possibilidades.

1) A referida norma urbanística ignora ritos legais, obrigatoriedades e diretrizes previstos na Constituição Federal e no Estatuto da Cidade, que foram grafados nestas cartas políticas como resultado de profundos debates sobre o direito à cidade, iniciados em meados dos anos de 1960, abafados e reprimidos ao longo da Ditadura Militar e finalmente retomados a partir do processo de redemocratização da década de 1980; particularmente, utiliza inadequadamente um instrumento da política urbana regulamentado pelo Estatuto da Cidade, a outorga onerosa do direito de construir. Tem-se assim um claro risco jurídico-político de deslegitimação do planejamento democrático, dos processos participativos e da produção das próprias leis, além do estabelecimento de sério precedente para uma gestão arbitrária.

2) Riscos no plano da economia são também bastante evidentes a partir de sua análise urbano-arquitetônica, à medida que seu inerente modelo de ocupação sobre área frágil e desprovida de infraestrutura necessariamente onera o mercado e os cofres públicos. No que diz respeito ao orçamento público, pode-se prontamente afirmar que a provisão técnica necessária para suprir a demanda por infraestrutura oriunda da ocupação consentida pela lei (seja referente ao saneamento básico, ao controle da poluição ou ao congestionamento viário consequentes do adensamento excessivo) provavelmente demandará vultosos investimentos na região em detrimento de outras áreas da cidade por ventura mais necessitadas, ainda que tais investimentos possam vir a ser realizados através de parcerias com o setor privado.

3) Quanto ao mercado imobiliário, a fragilidade de terrenos tão úmidos faz supor que a estabilidade das construções só será conseguida mediante soluções estruturais dispendiosas (ao se considerar gabaritos de 15 e 18 pavimentos como previstos para algumas zonas, custos serão elevados, por exemplo, para as fundações das edificações), sendo provavelmente necessárias, também, soluções para sistema de coleta 
de águas pluviais dentro do próprio lote, para posterior lançamento na rede.

4) Os exemplos colocados nos dois últimos itens esboçam que, para se viabilizar a ocupação da área com edificações de qualidade técnica e que estejam prontamente atendidas com infraesturutra adequada, muito provavelmente a tipologia habitacional ali produzida será de alto padrão e de alto preço. Em uma área com significativa população em vulnerabilidade socioeconômica, esta situação apresenta elevado risco social, pois por ela se desenham possibilidades de gentrificação a passos largos: por um lado, pode haver gradual deslocamento da população de baixa renda hoje residente para outras porções territoriais da cidade, possivelmente ainda mais periféricas e precárias; por outro lado, desta massa de desfavorecidos, aos que permanecerem, haverá como opção a ocupação irregular e predatória em áreas ainda mais frágeis, a partir da construção informal de habitações precárias localizadas nas terras com impeditivos legais, i.e., não passíveis ao parcelamento e à edificação, tais como faixas marginais, topos de morros, encostas, além das áreas úmidas que não tenham sido parceladas para 0 mercado formal e/ ou que não tenham sido utilizadas para a produção formal de habitação. Tratar-se-ia de ocupações em condições ambientais que tornam ainda mais precárias quaisquer deficiências de execução técnica, tipologia habitacional e padrão construtivo, que agigantam a vulnerabilidade econômica e os problemas de acesso a serviços e que, vistas fora de seu contexto, culpabilizam a população pobre tanto pelos danos ambientais quanto pelas mazelas sociais a que são submetidos.

5) Esta intrincada relação entre (ausência de) saneamento e (altíssimas) densidades urbanas aponta para certo risco inerente em relação a epidemias e, em situaçõeslimite, até mesmo perda de vidas humanas, o que no mínimo reacende a impressa da legislação urbanística desde já estar condicionando excessivos aportes financeiros que seriam desnecessários caso o PEU das Vargens possuísse parâmetros mais responsáveis.

6) Nesse sentido, os generosos parâmetros urbanísticos trazem consigo o risco, caso utilizados sem parcimônia, de uma completa descaracterização da paisagem da área, que hoje nas áreas onde é resultante de ocupação mais rarefeita é muitíssimo valorizada por seus moradores, e a disseminação do modelo excludente, que renega a cidade, dos condomínios fechados.

7) Por fim, e não menos importante, tem-se o risco que se relaciona com todos os demais: na dimensão geobiofísica, a possibilidade de um premente dano sobre a biodiversidade singular da área, o que acarreta grave risco de perda dos variados serviços e funções ecológicas da área, aqui mencionados, que têm suma importância para toda a cidade, sendo também relevantes nas escalas regional e global. Além disso, a perda por danos diretos (supressão e substituição de ecossistemas nativos) ou indiretos (poluição e efeito de borda entre a floresta e as ocupações), tanto na área da planície quanto nas encostas, resultará em um efeito em cascata reduzindo a capacidade desses ecossistemas em tamponar eventos climáticos extremos, como chuvas, enchentes e elevações da maré. A perda dessas funções ecossistêmicas suscetibilizará ainda mais a população humana assentada em áreas de fragilidade natural, sobretudo aquelas sob alta densidade de ocupação.

Como em toda análise de riscos, não podemos garantir que o que estamos prognosticando será de fato o futuro da área, isto é, se irá acontecer e nem quando acontecerá. Mas têm-se aqui fortes evidências que desenham contundentemente possibilidades negativas, que não podem ser ignoradas. Não nos resta, portanto, outra atitude a não ser o questionamento veemente da lei, pois consideramos o PEU das Vargens peça jurídica que desrespeita processos políticos, estimula modelo de ocupação irresponsável e, por isso, induz inúmeros riscos em variadas dimensões. Em outras palavras, se a ocupação da Baixada de Jacarepaguá já é por si mesma um hazard, o PEU das Vargens direciona a área para o campo dos riscos, tornando-a ainda mais vulnerável. A quem pode isto interessar?

\section{Referências bibliográficas:}

AcIoly, Claudio \& Davidson, Forbes (1998) - Densidade urbana. Rio de J aneiro; Mauad, 104p.

AneAs de CAstro, Susana D. (2000) - "Riesgos e periglos: una visión desde la Geografia". Scripta Nova. Barcelona, n. 60, p. 256-281. \{http://www. ub.es/geocrit/ sin-60.htm\}.

de Barros, Mario Thadeu Leme (2005) - "Drenagem urbana: bases conceituais e planejamento". In: PhILIPPI J R., Arlindo (ed.). Saneamento, saúde e ambiente. Fundamentos. Barueri, Manole, p. 221-265.

BECK, Ulrich (1998). La sociedade del riesgo. Hacia uma nueva modernidad. Barcelona, Editorial Paidós, 305p.

Bobbio, Norberto (1999). O positivismo jurídico. São Paulo, Icone.

dE CASTRo, Cléber Marques et. al. (2005) - "Riscos ambientais e geografia: conceituações abordagens e escalas". Anuário do Instituto de Geociências - UFRJ, vol. 28, no 2, p. 11-30. 
CostA, Lucıo (1969) Plano Piloto para urbanização da baixada compreendida entre a Barra da Tijuca, o Pontal de Sernambetiba e Jacarepaguá. Rio de J aneiro, Agência J ornalística Image.

Chartier, Roger (1990) - A história cultural. Lisboa, Difel.

DIAS, G. T. M.\& SILVA, C. G. (1984) - “Geologia de depósitos arenosos costeiros: exemplos ao longo do litoral fluminense". In: Restingas: Origem e Processos. Niterói, Universidade Federal Fluminense.

EgLeR, Claudio Antonio G. (1996) - “Risco ambiental como critério de gestão do território: uma aplicação à zona costeira brasileira". Território, v. 1, no 1, p. 31-41.

Foucault, Michel (2002) - As palavras e as coisas. São Paulo, Martins Fontes, 2002, 546 p.

Gonçalves, Guilherme Leite (2006) -“Os paradoxos da certeza do direito". Revista Direito GV. Vol. 2, no 1, p. 211-222.

Gondim, Linda Maria (1991) - "A participação popular no plano diretor: contribuições para a formulação de uma metodologia". Revista de Administração Municipal. Rio de J aneiro, Vol. 38, no 201, p. 14-29.

J ONES, David (1993) - "Environmental hazards in the 1990s: problems, paradigms and prospects". Geography, v. 78, no 2, p. 161-165.

Kelsen, Hans (1986) - Teoria Geral das Normas. Porto Alegre, Fabris.

LAmEgo, A. R (2007) - "Setores da evolução fluminense". 0 homem e a restinga. Rio de J aneiro, Ministério do Planejamento, Orçamento e Gestão - IBGE (edição fac-similar).

Lefebvre, Henri (1981) - The production of space. Oxford : Blackwell.

Marandola J R., Eduardo \& Hogan, J oseph (2004) - "Natural hazards: o estudo geográfico dos riscos e perigos". Ambiente \& Sociedade, Vol. VII, no 2, p. 95-109.

Montezuma, Rita de Cássia Martins et al. (2005) - Relatório técnico correspondente ao edital bid/feema corredor ecológico Frei Velloso Estrada da Vista Chinesa, s/nº Alto da Boa Vista. Rio de J aneiro".

Montezuma, Rita de Cássia Martins \& De Oliveira, Rogeiro Ribeiro (2010) - Os ecossistemas da Baixada de J acarepaguá". Arquitextos, Ano 10, no 116. \{http:// www. vitruvius.com. br/ revistas/ read/ arquitextos/ 10.116/3385\}.
Name, Leo (2010) - Análise da ocupação proposta pelo PEU das Vargens tendo como foco densidades, infraestruturas e condições ambientais. Arquitextos, Ano 10, no 116. \{http:// www. vitruvius. com. br/ revistas/ read/ arquitextos/ $10.116 / 3382\}$

Nino, Carlos Santiago (1998) - Introducción al análisis del derecho. Buenos Aires, Editorial Astrea.

November, Valérie (2006) - "Le risque comme objet géographique". Cahiers de géographie Du Québec, Vol. 50, no 141, p. 289-296.

November, Valérie (1994) - "Risques naturels et croissance urbaine: réflexion théorique sur la nature et Le role Du risque dans I'espace urbain". Revue de géographie alpine, № 4, p. 113-123.

de Oliveira, Isabel Cristina Eiras (2001) - Estatuto da Cidade: para compreender... Rio de J aneiro, IBAM, 64p.

DE OlivelRA, Rogeiro Ribeiro. (Org.) (2005) - As marcas do homem na floresta: História Ambiental de um trecho urbano de Mata Atlântica. Rio de J aneiro: Ed. PUC-Rio, 232p.

PAGE, Talbot (1978) - "A generic view of tocix chemicals and similar risk". Ecology Law Quaterly, v. 7, no 2, p. 207.

Rezende, Vera (1982) - Planejamento urbano e ideologia. Rio de J aneiro : Civilização Brasileira, 126p.

Rezende, Vera \& Leitão, Gerônimo (2003) - "Plano Piloto para a Barra da Tijuca e Baixada de J acarepaguá, avaliação dos ideais modernistas após três décadas". Anais do 50 Seminário Docomomo Brasil. São Carlos.

Ribeiro, Luiz César de Queiroz \& Cardoso, Adauto Lucio (1990) - "Plano Diretor e gestão democrática da cidade". In: De Grazia, Grazia (org.). Plano Diretor: Instrumento de Reforma Urbana. Rio de J aneiro, Fase, p. 70-88.

SAntos, Boaventura de Sousa (2003) - Um discurso sobre as ciências. São Paulo, Cortez, 94 p.

PCRJ (2006) - Relatório da Revisão do Plano Diretor Decenal da Cidade. Rio de Janeiro. \{http:// aspasiacamargo.com. br/docs/ plano diretor relatorio.pdf

SмIтH, Keith (1992) - Environmental hazards: assessing risk and reducing disaster. London, Routledge, $324 \mathrm{p}$.

SовотA, Katharina (1996) - "Don't mention the norm!". International Journal for Semiotics of Law. Vol. IV, no 10, p. 45-60. 
RISCOS - Associação Portuguesa de Riscos, Prevenção e Segurança

DE SouzA, Marcelo Lopes (2002) - Mudar a cidade. Rio de J aneiro, Bertrand Brasil, 560p.

Tuccl, Carlos Eduardo Morelli (2005) - “Águas urbanas: interfaces de gerenciamento". In: PHILIPPI J R., Arlindo (ed.). Saneamento, saúde e ambiente. Fundamentos. Barueri, Manole, p. 375-411.
White, Gilbert F. (1975) - "La investigacion de los riesgos naturales". In: ChORLEy, Richard J . (ed.). Nuevas tendencias en Geografia. Madrid, Instituto de Estudios de Administracion Local, p. 281-319. 